\title{
Recent Progress in Understanding and Projecting Regional and Global Mean Sea Level Change
}

\author{
Peter U. Clark ${ }^{1}$ • John A. Church ${ }^{2}$. Jonathan M. Gregory ${ }^{3,4}$ • Anthony J. Payne ${ }^{5}$
}

Published online: 10 October 2015

(C) Springer International Publishing AG 2015

\begin{abstract}
Considerable progress has been made in understanding the present and future regional and global sea level in the 2 years since the publication of the Fifth Assessment Report (AR5) of the Intergovernmental Panel on Climate Change. Here, we evaluate how the new results affect the AR5's assessment of (i) historical sea level rise, including attribution of that rise and implications for the sea level budget, (ii) projections of the components and of total global mean sea level (GMSL), and (iii) projections of regional variability and emergence of the anthropogenic signal. In each of these cases, new work largely provides additional evidence in support of the AR5 assessment, providing greater confidence in those findings. Recent analyses confirm the twentieth century sea level rise, with some analyses showing a slightly smaller rate before 1990 and some a slightly larger value than reported in the AR5. There is now more evidence of an acceleration in the rate of rise. Ongoing ocean heat uptake and associated thermal expansion have continued since 2000, and are consistent with ocean thermal expansion reported in the AR5. A significant amount of heat is being stored deeper
\end{abstract}

This article is part of the Topical Collection on Sea Level Projections

Peter U. Clark

clarkp@geo.oregonstate.edu

1 College of Earth, Ocean, and Atmospheric Sciences, Oregon State University, Corvallis, OR 97330, USA

2 CSIRO Oceans and Atmosphere Flagship, Hobart, TAS 7000, Australia

3 NCAS-Climate, University of Reading, Reading RG6 6BB, UK

4 Met Office Hadley Centre, Exeter EX1 3PB, UK

5 School of Geographical Sciences, University of Bristol, Bristol BS8 1SS, UK in the water column, with a larger rate of heat uptake since 2000 compared to the previous decades and with the largest storage in the Southern Ocean. The first formal detection studies for ocean thermal expansion and glacier mass loss since the AR5 have confirmed the AR5 finding of a significant anthropogenic contribution to sea level rise over the last 50 years. New projections of glacier loss from two regions suggest smaller contributions to GMSL rise from these regions than in studies assessed by the AR5; additional regional studies are required to further assess whether there are broader implications of these results. Mass loss from the Greenland Ice Sheet, primarily as a result of increased surface melting, and from the Antarctic Ice Sheet, primarily as a result of increased ice discharge, has accelerated. The largest estimates of acceleration in mass loss from the two ice sheets for 2003-2013 equal or exceed the acceleration of GMSL rise calculated from the satellite altimeter sea level record over the longer period of 1993-2014. However, when increased mass gain in land water storage and parts of East Antarctica, and decreased mass loss from glaciers in Alaska and some other regions are taken into account, the net acceleration in the ocean mass gain is consistent with the satellite altimeter record. New studies suggest that a marine ice sheet instability (MISI) may have been initiated in parts of the West Antarctic Ice Sheet (WAIS), but that it will affect only a limited number of ice streams in the twenty-first century. New projections of mass loss from the Greenland and Antarctic Ice Sheets by 2100 , including a contribution from parts of WAIS undergoing unstable retreat, suggest a contribution that falls largely within the likely range (i.e., two thirds probability) of the AR5. These new results increase confidence in the AR5 likely range, indicating that there is a greater probability that sea level rise by 2100 will lie in this range with a corresponding decrease in the likelihood of an additional contribution of several tens of centimeters above the likely range. In view of the comparatively limited 
state of knowledge and understanding of rapid ice sheet dynamics, we continue to think that it is not yet possible to make reliable quantitative estimates of future GMSL rise outside the likely range. Projections of twenty-first century GMSL rise published since the AR5 depend on results from expert elicitation, but we have low confidence in conclusions based on these approaches. New work on regional projections and emergence of the anthropogenic signal suggests that the two commonly predicted features of future regional sea level change (the increasing tilt across the Antarctic Circumpolar Current and the dipole in the North Atlantic) are related to regional changes in wind stress and surface heat flux. Moreover, it is expected that sea level change in response to anthropogenic forcing, particularly in regions of relatively low unforced variability such as the low-latitude Atlantic, will be detectable over most of the ocean by 2040 . The east-west contrast of sea level trends in the Pacific observed since the early 1990s cannot be satisfactorily accounted for by climate models, nor yet definitively attributed either to unforced variability or forced climate change.

Keywords Global mean sea level · Regional sea level · Sea-level observations $\cdot$ Sea-level projections

\section{Introduction}

Understanding and projecting regional and global mean sea level change is of critical importance to assessing socioeconomic impacts and for planning for adaptation in the highly populated low-lying coastal zones of the world. Today, about $10 \%$ of the world's population ( $>600$ million people) and about $65 \%$ of the world's cities with populations of greater than 5 million are located at elevations less than $10 \mathrm{~m}$ above sea level [1], and 150 million people live within $1 \mathrm{~m}$ of the high tide level [2]. Over the last four decades, rapid migration towards the coast and development has significantly increased exposure of populations and assets to extreme sea level events, with about 270 million people and US\$13 trillion worth of assets being exposed to such events in 2010 [3]. Continued population growth, economic development, and urbanization, combined with additional sea level rise and associated increase in frequency of extreme sea level events, will further increase the risk and impacts in coastal zones [4].

Planning for and adapting to sea level change requires an assessment of the expected magnitude of change and its uncertainties. Working Group I (WG1) of the Fifth Assessment Report (AR5) of the Intergovernmental Panel on Climate Change (IPCC) assessed sea level change from several perspectives: (1) past sea level change with an emphasis on previous warm intervals, the past millennium, and over the instrumental period (since 1700); (2) contributions to global mean sea level (GMSL) rise during the instrumental period;
(3) projections of GMSL change during the twenty-first century and over the longer term (to 2500); (4) projections of twenty-first century regional sea level change; and (5) projections of twenty-first century sea level extremes and waves [5].

The calibrated uncertainty language of the IPCC uses terms to indicate the assessed likelihood of an outcome or a result. Where referring to the IPCC assessment of likelihood of an outcome, we follow their convention in italicizing the terms. For example, likely means that there is a probability of two thirds or more than the outcome may lie within the likely range whereas very likely means a probability of at least $90 \%$ within the range. Uncertainty is quantified using $90 \%$ uncertainty intervals unless otherwise stated. The $90 \%$ uncertainty interval, reported in square brackets (e.g., 0.21 [0.16 to 0.26$] \mathrm{m}$ ), is expected to have a $90 \%$ likelihood of covering the value that is being estimated; it is only specific to the very likely range when identified as such.

The AR5 concluded that twenty-first century global mean surface air temperature (SAT) change is likely (i.e., two thirds probability, NB not very likely) to lie within the 5-95\% range (i.e., from the 5 th to the 95 th percentile) of the Coupled Model Intercomparison Project Phase 5 (CMIP5) model projections; this is a measure of the spread resulting from different choices of structure and parameters in the models [6]. Accordingly, the AR5 interpreted the 5-95\% range of model results as the likely range for each of the GMSL rise contributions that is projected on the basis of CMIP5 results (thermosteric, glaciers, ice sheet surface mass balance) [5], and for consistency, the model 5-95\% range was also interpreted as likely for projected contributions from rapid ice sheet dynamics and land water storage. As an example, reporting a likely range of projected sea level rise of 0.2 to $0.8 \mathrm{~m}$ means that it is likely (i.e., at least $66 \%$ probability) that sea level will lie within the 0.2 to $0.8 \mathrm{~m}$ uncertainty range, and a probability of $33 \%$ or less that it will lie outside that range (not necessarily symmetrically distributed). The AR5 was not able to assess a very likely range for projected GMSL rise because there was (and still is) no assessment available of the very likely range for global mean SAT change, and because the probability of ice sheet dynamical changes that would give rise to greater values could not be robustly quantified.

The AR5 assessment of sea level change made three important advances beyond the Fourth Assessment Report (AR4) [7]. Firstly, the AR5 demonstrated that, when an allowance for potential ice sheet contributions is included, the observed GMSL rise is consistent with the sum of the estimated contributions since 1900, and that models and observations are consistent regarding the contributions from thermal expansion and glaciers over the last 50 years. The budget was closed for 1993-2010 (corresponding to the period of continuous satellite observations of sea level and ice sheets), and for 1971-2010 (with reasonable estimates of ice sheet contributions). These findings imply improved physical understanding 
of the causes of past GMSL change and greater confidence in the reliability of models for making projections.

Secondly, the AR5 included future rapid changes in ice sheet dynamics in its sea level projections. This could not be done in the AR4 because there were no existing models and insufficient scientific understanding of the accelerations in ice sheet outflow that had only recently been observed [7]. Accordingly, the AR4 did not provide a best estimate or likely range of twenty-first century sea level change. By the time of the AR5, understanding and modeling of these contributions from ice sheet dynamics had developed sufficiently to allow an assessment of a likely increase of global mean sea level for each of the four representative concentration pathways (RCPs) of future atmospheric composition [8,9] used by WG1 for climate projections (for example, 0.52 to $0.98 \mathrm{~m}$ by 2100 for RCP8.5) [5]. The AR5 could not exclude the possibility of higher sea levels, but concluded that only the collapse of the marine-based sections of the Antarctic ice sheet, if initiated, could cause GMSL to rise substantially higher (estimated at several tenths of a meter) than the likely range in the twenty-first century [5]. However, significant uncertainties, particularly related to the dynamical Antarctic ice sheet contribution, remain.

Thirdly, the inclusion of the effect of rapid ice sheet dynamical change meant that the AR5, unlike the AR4, was able to make projections of the regional distribution of sea level change. This led to the conclusion that, by the end of the twenty-first century, it is very likely that regional sea level rise will be positive over about $95 \%$ of the world ocean, and that about $70 \%$ of the global coastlines are projected to experience a relative sea level change within $20 \%$ of the GMSL change [5].

The AR5 projections of twenty-first century sea level change have been criticized for taking a "moderate line" [10], for being "conservative" [11], and for being "misleading" [12]. As explained by Church et al. [13], such criticisms are based in part on a misunderstanding of how the results are reported, particularly with regard to the IPCC calibrated uncertainty language and on whether the results were given for 2081-2100 or for 2100. For example, under the highest scenario considered, the AR5 reported a likely range (with two thirds probability) of 0.45 to $0.82 \mathrm{~m}$ for 2081-2100 and 0.52 to $0.98 \mathrm{~m}$ for 2100 , but Kerr [10] reported the latter as "a worst case of $1 \mathrm{~m}$."

In the two and a half years since March 2013, the cutoff date for literature assessed by the AR5, there has been considerable progress in understanding several of the key issues on sea level change discussed by the AR5. In this review, we summarize the main findings by the AR5 and discuss how literature published since the cutoff date compares to the AR5 assessment, including whether any modification of that assessment is required, and with particular attention to projections beyond the likely range.

\section{Historical Sea Level}

\section{The Tide-Gauge Record ( 1770-2015)}

The AR5 [5,14] concluded that the trend in GMSL for 1900 to 2010 was $1.7 \pm 0.2 \mathrm{~mm} \mathrm{year}^{-1}$ (1.5 mm year ${ }^{-1}$ from 1901 to 1990), and accelerated during the twentieth century in the presence of multi-decadal variability, with estimates that ranged from $0.000[-0.002$ to 0.002$] \mathrm{mm} \mathrm{year}^{-2}$ to 0.013 [0.007 to 0.019$] \mathrm{mm}$ year $^{-2}$. New and longer tide-gauge records have become available since the AR5. Updates of two of the GMSL reconstructions used in the AR5 give $1.77 \pm 0.28$ [15] and $1.9 \pm 0.3 \mathrm{~mm}$ year $^{-1}$ since 1900 (and $3.1 \pm$ $0.6 \mathrm{~mm} \mathrm{year}^{-1}$ for 1993 to 2009) [16], in the upper half of the AR5 range. Hay et al. [17] considered the "fingerprints" of mass loss from glaciers and ice sheets in their reconstruction of GMSL. These effects on regional sea level are due to the change in the geopotential field (jointly determined by gravitation and Earth rotation) and the elastic response of the lithosphere, both practically instantaneous and caused by the geographical redistribution of mass on the Earth's surface when mass is transferred from land into the ocean. As shorthand, we later (section "Regional Projections and Emergence Time of the Forced Signal") refer to these effects as "GeLi." By this method, they estimated a trend of $1.2 \pm 0.2 \mathrm{~mm}$ year $^{-1}$ for 1901 to 1990 , which overlaps the AR5 range of $1.5 \pm 0.2 \mathrm{~mm}_{\text {year }}{ }^{-1}$ for the corresponding period, but is lower primarily because their estimate has very little sea level change during 1950 1970. Including the GeLi fingerprints is an advance over assuming geographically uniform sea level contributions from land ice (as in Church and White [18]), but estimating the magnitude of the weight factors for the many fingerprints used by Hay et al. in the presence of large regional decadal variability is challenging given the time-varying and incomplete distribution of observations. Hamlington and Thompson [19] drew attention to the tide-gauges from the Arctic, Alaska and Japan that are included in Hay et al. [17] but not the other reconstructions. The Arctic gauges have negative trends for 1950-1970, and high-latitude gauges in general have the most uncertain glacial isostatic adjustment [16]. However, Hay (personal communication) reports that their results are essentially unchanged if they use the same tide-gauge data set as Church and White [18].

Becker et al. [20], Bos et al. [21], Beenstock et al. [22], and Dangendorf et al. [23] suggested that long-term variability in local and global mean sea level has resulted in previous studies underestimating uncertainties. Using refined uncertainty estimates, Becker et al. and Dangendorf et al. estimated a larger uncertainty, due to unforced and naturally forced variability, and thus argued the minimum long-term anthropogenic GMSL trend since 1900 is 1 and $0.6 \mathrm{~mm}_{\text {year }}{ }^{-1}$, respectively (both at the $99 \%$ confidence level). Since the variability can be of either sign, these studies also imply the possibility that 
the anthropogenic GMSL trend could be larger than observed, and partially offset by variability. Beenstock et al. [22] argued that tide-gauges with trends that were not significantly different to zero should be excluded from the global mean, that the longer tide-gauge time series are from locations with larger rates of sea level rise, and therefore, that GMSL estimates reported in the AR5 are biased high. We disagree with the first argument, which could be made to disprove the existence of any global mean trend that is partly obscured by local variability, whereas averaging over many locations reduces that variability. The second argument is doubtful because it assumes constant regional patterns of forced sea level change through the century.

A number of different techniques have been used to estimate acceleration of local relative sea level (for example, see Visser et al. [24]), but the results are controversial (see for example Kenigson and Han [25]; Piecuch and Ponte [26]). Haigh et al. [27] demonstrated the difficulty of estimating accelerations from local tide-gauge observations, the necessity for long time series (Douglas [28] argued that almost 50 years was required), and the importance of removing unforced and naturally forced variability.

There are now more estimates of acceleration of GMSL over the nineteenth to twentieth century and these are generally larger than those available at the time of the AR5, ranging from $0.0042 \pm 0.0092$ [15] to $0.02 \pm 0.01 \mathrm{~mm}$ year $^{-2}$ [16] (see Cahill et al. [29]; Hay et al. [17]; Hogarth [30]; Olivieri and Spada [31]; Spada et al. [32] for intermediate estimates). Jorda [33] estimated that at least $2.2 \mathrm{~mm}_{\text {year }}{ }^{-1}$ of the recent sea level trend estimated from altimetry cannot be attributed to unforced multidecadal variability, implying that the change in trend between 1900 and 1990 and the altimeter period is at least partly forced.

In summary, recent analyses confirm the twentieth century sea level rise, with some analyses showing a slightly smaller rate before 1990 and some a slightly larger value than reported in the AR5. There is now more evidence of an acceleration in the rate of rise.

\section{The Satellite Altimeter Period}

According to the AR5, the rate of sea level rise measured by the TOPEX/POSEIDON/Jason $1 / 2$ satellite altimeter missions over 1993 to 2012 was $3.2 \pm 0.4 \mathrm{~mm}_{\text {year }}{ }^{-1}$, with interannual variability that was related to climate variability, particularly the El Nino-Southern Oscillation phenomenon. Cazenave et al. [34] found a deceleration from the first to the second decade of the altimeter record, but demonstrated that there was no significant reduction of the underlying rate of sea level rise over this two-decade period if the effects of interannual climate variation on the storage of water on land (particularly in Australia; Fasullo et al. [35]) and thermal expansion are excluded. Confirming the importance of interannual variability,
Yi et al. [36] have shown that since the La Niña event of 2010, the rate of sea level rise has been substantially larger than the 1993-2015 average as a result of a decrease of water stored on land, increased ocean thermal expansion, and faster loss of mass from the ice sheets (particularly Greenland).

As a result of a major and ongoing effort to improve the quality of the altimeter records [37], the ERS-1/ERS-2/ Envisat GMSL trend over 1993 to 2010 was revised upward from $1.59 \pm 0.5$ to $2.36 \pm 0.5 \mathrm{~mm}$ year $^{-1}$, compared with their TOPEX/Jason estimate of $2.98 \pm 0.4 \mathrm{~mm}$ year ${ }^{-1}$ over the same period. Watson et al. [38] examined the quality of the TOPEX/ Jason $1 / 2$ altimeter record by a careful comparison with sea level measured by coastal and island tide gauges. They found small but significant trends in the sea level biases, mostly in the first 6 years (the TOPEX satellite) of the record. After correction for these biases, they estimated a corrected GMSL trend over 1993 to mid-2014 of 2.6 to $2.9 \pm 0.4 \mathrm{~mm} \mathrm{year}^{-1}$ (dependent on the vertical land motion correction adopted), and found an acceleration of $0.041 \pm 0.058 \mathrm{~mm}$ year $^{-2}$, in contrast to the deceleration reported by Cazenave et al. [34]. (The acceleration is not significantly different from zero, but it is significantly different from the deceleration over the same period of $-0.057 \pm 0.058 \mathrm{~mm}^{\text {year }}{ }^{-2}$ if these bias drifts were not corrected.) Reprocessing of the TOPEX record is currently underway and should shed light on the validity or otherwise of these corrections and revised GMSL estimates.

Analysis of 13 years (2002-2015) of data from GRACE, Global Navigation Satellite System, satellite laser ranging and the Ocean Circulation and Climate of the ocean bottom pressure [39] give an acceleration of global mass (non-steric) component of $0.04 \pm 0.09 \mathrm{~mm} \mathrm{year}^{-2}$, similar to the above satellite altimeter estimate (for latitudes less than $65^{\circ}$ ) but with larger uncertainty estimates. This ocean mass is the balance between accelerated mass loss from the Greenland and West Antarctic Ice Sheets and increased mass gain in land water storage and parts of East Antarctica, and decreased mass loss from glaciers in Alaska and some other regions.

The recent analyses confirm that the rate of sea level rise since 1993 is larger than prior to 1990, with suggestions of a slightly smaller rate than reported in the AR5 and with a small (but not statistically significant) acceleration.

\section{Sea Level Contributions}

\section{Steric Sea Level Change}

The AR5 estimated rates of thermal expansion of 0.8 [0.5 to $1.1] \mathrm{mm} \mathrm{year}^{-1}$ for 1971 to 2010 and 1.1 [0.8 to 1.4 ] $\mathrm{mm}$ year $^{-1}$ for 1993 to 2010 . Some of the studies discussed in the AR5 (e.g., Lyman et al. [40]), but not all (e.g., [41,42]), reported a sharp spike in ocean heat uptake in the early 2000 s followed by a slowing of the rate of heat uptake (and thus 
ocean thermal expansion). Since then, Abraham et al. [43] published a major review on the evolving observing system, the reduction of XBT biases, and estimates of heat content and thermosteric sea level trends over different periods, generally confirming the AR5 assessment of trends since 1971 and 1993. These estimates are dependent on a range of uncertainties, including ocean climatologies used, vertical resolution $[44,45]$, and mapping techniques [46].

The apparent surface warming "hiatus" has prompted many studies, including a focus on ocean heat uptake, but with less attention specifically addressing the related thermosteric sea level change. Balmaseda et al. [47] and Chen and Tung [48] demonstrated an ongoing ocean heat uptake during the hiatus, but with a greater accumulation deeper in the water column, between the depth of most previous upper ocean estimates (300 and $700 \mathrm{~m}$ ) and $2000 \mathrm{~m}$. Balmaseda et al. [47] demonstrated a clearer response to volcanic eruptions than earlier studies (e.g., Domingues et al. [49]) and a greater rate of heat uptake after 2000 then in the 1990s. Chen and Tung [48] argued that most of the heat uptake occurred in the North Atlantic and in the Southern Ocean whereas Nieves et al. [50] argued for the importance of heat uptake in the 100- to 300-m layer of the Indian and Pacific Oceans.

Ocean heat content changes are directly related to top of the atmosphere net radiation fluxes [51]. Allan et al. [52] used atmospheric reanalysis and twentieth century simulations to extend the CERES satellite radiation observations of the Earth's global energy balance (anchored to the estimates of ocean energy uptake; Loeb et al. [53]) back to the 1980s. Smith et al. [54] extended these series back to 1960 and demonstrated an increasing ocean heat uptake, the impact of volcanic eruptions, and that the spike in ocean heat uptake and subsequent decrease in the rate of ocean warming after 2000 in some studies was probably an artifact of errors in XBT bias corrections and/or incomplete ocean coverage. Wunsch and Heimbach [55] used a sophisticated data assimilation technique to infer a deep ocean cooling, in direct contrast to the direct observations of Purkey and Johnson [56]. The reason for this difference in the Wunsch and Heimbach results is unclear but could relate to the omission of the geothermal heat flux from the ocean seafloor (approximately equivalent to the difference between their results to the direct observations) or the dominance of upper ocean observations over the sparse deep observations in their analysis.

Extended altimeter observations of sea surface height, GRACE observations of ocean mass, and Argo observations of upper ocean thermal expansion have shown an approximate closure of the sea level budget (see Leuliette [57] for a review). von Schuckmann et al. [58] and Dieng et al. [59] argued that ocean heat-uptake estimates were biased low because of inadequate coverage and mapping, particularly in the region of the tropical Asian archipelago. Uncertainties in the sea level budget are too large for the deep ocean contribution to be inferred [58-60].
Durack et al. [61] found that, in the CMIP Phase 3 (CMIP3) and CMIP5 climate model simulations, $60 \%$ of the heat uptake occurred in the Southern Hemisphere. In contrast, the observational estimates ranged from about 35 [62] to about $50 \%$ [49], suggesting that historical ocean heat content estimates may be biased low by various amounts because of lack of data in the Southern Hemisphere. Based on Argo data from 2006 to 2014, Roemmich et al. [63] found an even larger ratio of Southern to Northern Hemisphere ocean heat uptake (67 to $98 \%$ ) possibly as a result of greater negative aerosol forcing in the Northern Hemisphere and/or ocean heat uptake processes. This larger ratio raises concern about the use of the model results for adjusting the observational estimates, as suggested by Durack et al. [61]. One of the mapping techniques used in Roemmich et al. [63] also directly addressed the mapping deficiencies in the tropical Asian archipelago identified in von Schuckmann et al. [58] and indicates that over the 2006 to 2014 period, the thermal expansion in the upper $2000 \mathrm{~m}$ was $0.8 \pm 0.5 \mathrm{~mm}_{\text {year }}{ }^{-1}$ (Didier Monselesan, personal communication), and $0.9 \pm 0.5 \mathrm{~mm} \mathrm{ear}^{-1}$ for the full depth ocean (using the [56] abyssal ocean estimates), close to the AR5 estimate for 1993-2010.

Halosteric trends over the historical period from 1950 to 2010 are important regionally in reinforcing thermosteric trends in the Pacific and counteracting them in the Atlantic (generally of order $25 \%$ of thermosteric trends) (Durack et al., 2015) but are not important for the global ocean steric change. Purkey et al. [64] demonstrated agreement between regional ocean-mass trends determined from GRACE data and the difference between altimeter sea level observations and ocean steric sea level change.

In summary, recent analyses clearly indicate an ongoing ocean heat uptake and associated thermal expansion since 2000, with a significant amount of heat being stored deeper in the water column and with the largest storage in the Southern Ocean. Quantitatively, the new results are consistent with ocean thermal expansion reported in the AR5, and with a larger rate of heat uptake since 2000 compared to the previous decades.

\section{Glacier Mass Loss}

Glacier mass loss was a major contributor to sea level rise during the twentieth century. The AR5 estimated sea level contributions from glaciers of 0.69 [0.61 to 0.77$] \mathrm{mm}_{\text {year }}{ }^{-1}$ for 1901-1990, 0.68 [0.31 to 1.05$] \mathrm{mm}$ year $^{-1}$ for $1971-2010$ and 0.86 [0.49 to 1.23$] \mathrm{mm} \mathrm{year}^{-1}$ for 1993-2010. The estimates diverge most before 1950 and after 2003. Extensions and corrections to the glacier inventory, combined with a significantly increased number of geodetic mass-balance and glacier-length measurements, have led to convergence of the various estimates such that they now agree within uncertainties over all the periods considered [65]. There have been 
only small changes in the average of these estimates, and values are consistent with those reported in the AR5, increasing confidence in those estimates.

\section{Greenland Ice Sheet}

The AR5 found that the Greenland ice sheet has lost mass over the last two decades and that the rate of loss has increased [66]. Mass loss was about equally partitioned between changes in surface mass balance (SMB, snow accumulation minus runoff) and increased discharge into the ocean as icebergs, with the former dominating in southwest, central-north, and northeast sectors and the latter in southeast and central-west sectors. While on average, SMB has become progressively less positive over the last two decades, there have been considerable spatial and temporal variations in rates of discharge. Observations indicated that the contribution to GMSL had very likely increased from 0.09 [ -0.02 to 0.20$] \mathrm{mm}$ year $^{-1}$ for $1992-2001$ to 0.59 [0.43 to 0.76$] \mathrm{mm} \mathrm{year}^{-1}$ for $2002-$ 2011, with a total of $\sim 8.0 \pm 1.4 \mathrm{~mm}$ from 1992 to 2012, implying an acceleration of $\sim 0.05$ [0.02 to 0.08$] \mathrm{mm}_{\text {year }}{ }^{-2}$. These numbers include the contribution from glaciers peripheral to the ice sheet, because some methods used to measure mass loss are unable to separate them from the ice sheet.

Several studies published since the AR5 using various remote-sensing techniques support the AR5 conclusions. Based on laser altimetry measurements from IceSat, Csatho et al. [67] estimated a contribution from the Greenland ice sheet to GMSL of $0.68 \mathrm{~mm}$ year $^{-1}$ for 2003-2009. Based on gravity measurements from GRACE, Velicogna et al. [68] found mass loss across much of the ice sheet for the 20032013 period, and reported a contribution to GMSL rise of 0.77 $\pm 0.16 \mathrm{~mm}$ year $^{-1}$, with an acceleration of $0.069 \pm$ $0.003 \mathrm{~mm}$ year $^{-2}$. The largest losses occurred in the southeastern and northwestern sectors of the ice sheet ( $70 \%$ combined), while the southwestern sector experienced the greatest acceleration in mass loss. SMB accounted for $\sim 67 \%$ of the total mass loss during this period. Using Operation IceBridge, ice thickness measurements to better constrain discharge rates for 178 marine-terminating outlet glaciers, Enderlin et al. [69] found that 15 glaciers accounted for $77 \%$ of the total mass loss by discharge since 2000 and only 4 glaciers accounted for $50 \%$ of the total. The contributions of SMB and discharge were nearly equal until $\sim 2006$, but the contribution of discharge has since decreased, with a corresponding increase in mass loss due to SMB changes, which has reached $84 \%$ of the total since 2009. Enderlin et al. [69] estimated that the contribution to GMSL increased from $0.43 \pm 0.09 \mathrm{~mm}_{\text {year }}{ }^{-1}$ over 2000-2005 to $0.73 \pm 0.05 \mathrm{~mm} \mathrm{year}^{-1}$ over 2005-2009 and $1.05 \pm 0.14 \mathrm{~mm}$ year $^{-1}$ over 2009-2012, with an acceleration of $0.08 \pm 0.02 \mathrm{~mm}$ year $^{-2}$, giving a total contribution of $8.23 \pm$ $0.93 \mathrm{~mm}$ over 2000-2012. Wouters et al. [70] and $\mathrm{Wu}$ and Helfin (2015) cautioned that these calculated accelerations are for short periods and are affected by longer term climate variability. Based on radar altimetry measurements from CryoSat-2 for the 3-year period starting in January 2011, Helm et al. [71] confirmed the recent high contribution to GMSL $\left(1.04 \pm 0.07 \mathrm{~mm} \mathrm{year}^{-1}\right)$, with greatest elevation changes on the western, southeastern, and northeastern margins. Based on data from several measurement platforms, Khan et al. [72] also documented recent pronounced thinning of the northeast Greenland ice stream. Van Angelen et al. [73] emphasized the importance of the observed persistent negative anomalies in the summertime North Atlantic oscillation (NAO) index for the recent changes in the observed SMB, which exceeded the CMIP5 simulations, supporting the AR5 conclusion that internally generated regional climate variability has been the dominant cause of recent negative SMB [5]. The CMIP5 models do not consistently project negative anomalies in the summertime in the NAO index and a return of the NAO to more positive values may lead to a partial recovery in the SMB changes.

In summary, recent publications indicate an acceleration of mass loss from the Greenland ice sheet, primarily as a result of increased surface melting. The reported contributions and the computed accelerations are at the upper end of the likely range assessed in the AR5.

\section{Antarctic Ice Sheet}

In the near absence of surface melting and runoff, Antarctica's mass budget is dominated by snow accumulation and ice discharge across the grounding line into floating ice shelves. In the AR5 assessment, the Antarctic ice sheet (including the peripheral glaciers) was losing mass and likely contributed 0.27 [0.16 to 0.37$] \mathrm{mm}$ year $^{-1}$ to GMSL over $1993-2010$, and 0.41 [0.20 to 0.61$] \mathrm{mm} \mathrm{year}^{-1}$ over 2005-2010, suggesting an acceleration of $\sim 0.01[-0.02$ to 0.05$] \mathrm{mm}$ year $^{-2}$ [66]. The acceleration has been caused by an increase in discharge in the Antarctic Peninsula and the Amundsen Sea sector of West Antarctica, and was somewhat offset by a mass gain over East Antarctica due to increased snowfall.

Papers published since 2013 largely corroborate the AR5 assessment. Based on GRACE measurements for the period 2003-2013, Velicogna et al. [68] estimated that the ice sheet has contributed to GMSL rise at a rate of $0.18 \pm$ $0.12 \mathrm{~mm} \mathrm{year}^{-1}$ with an acceleration of $0.03 \pm$ $0.01 \mathrm{~mm} \mathrm{year}^{-2}$; greatest rates of mass loss are from the Amundsen Sea area (equivalent to $0.32 \pm 0.02 \mathrm{~mm}$ year $^{-1}$ ), which accounts for $94 \%$ of the mass loss from West Antarctica and the Antarctic Peninsula, with loss from both areas being dominated by dynamics. Dronning Maud Land in East Antarctica experienced a mass gain accounting for a fall in GMSL of $0.17 \pm 0.02 \mathrm{~mm}$ year $^{-1}$ since 2008 [74]. Harig and Simons [75] used techniques to increase the spatial resolution of the GRACE data, thus better resolving regional variations, 
and arrived at similar estimates. As noted above, Wouters et al. [70] and Wu and Helfin (2015) cautioned that these calculated accelerations are for short periods and are affected by longerterm climate variability.

Measurements of recent elevation changes over the Antarctic ice sheet from CryoSat-2 show a contribution to GMSL rise of $0.45 \pm 0.14 \mathrm{~mm}_{\text {year }}{ }^{-1}$ since $2010,75 \%$ of which is derived from the Amundsen Sea sector of West Antarctica [76], and a contribution of $0.35 \pm 0.23 \mathrm{~mm}_{\text {year }}{ }^{-1}$ since 2011 [71]. Sutterley et al. [77] compared four independent estimates of the mass balance of the Amundsen Sea area, identified by all studies as the primary region of Antarctica currently experiencing mass loss. The four methods agree in terms of mass loss and acceleration in loss at the regional scale. The contribution to GMSL rise was $0.23 \pm$ $0.01 \mathrm{~mm} \mathrm{year}^{-1}$ over 1992-2013 and $0.28 \pm 0.03 \mathrm{~mm}_{\text {year }}{ }^{-1}$ over 2003-2011.

Rignot et al. [78] showed that the grounding lines of glaciers draining the Amundsen Sea sector of West Antarctica retreated by up to $35 \mathrm{~km}$ from 1992 to 2011 . These rapid retreats have proceeded along regions where the bed slopes downwards away from the coast, the configuration which is potentially subject to the marine ice sheet instability. Upstream of the 2011 grounding line positions, there are no major bed obstacles that would prevent irreversible retreat in this sector of the West Antarctic ice sheet [78]. Ice sheet model experiments suggest that current retreat of Pine Island Glacier (PIG) [79] and Thwaites Glacier (TG) [80] may be irreversible.

The AR5 concluded that the changes in the Amundsen Sea region are due to high ocean heat flux causing thinning of ice shelves and grounded ice and grounding line retreat. Schmidtko et al. [81] documented warming at the bottom of the Amundsen and Bellingshausen seas that is linked to increased heat content and to a shoaling of the mid-depth temperature maximum over the continental slope, allowing warmer, saltier circumpolar deep water (CDW) access to the shelf in recent years. Paolo et al. [82] found that thinning of Antarctic ice shelves has increased since 1994, being most intense in the Amundsen and Bellingshausen regions. The average thickness of ice shelves has decreased by $5-8 \%$ in less than two decades, with some shelves thinning at rates that imply complete loss in less than 100 years. Greatest thinning has occurred near the deep grounding lines, consistent with ocean forcing from increased flux of CDW across the continental shelf.

In summary, recent publications support the AR5 assessment that mass loss from the Antarctic ice sheet is accelerating, with most of that loss coming from the Amundsen Sea sector of the WAIS. Observations and model simulations since the AR5 suggest that this acceleration may be associated with a marine ice sheet instability that may have been initiated in parts of the WAIS, and that this may have been triggered by increased flux of CDW across the continental shelf. There are also indications of increased accumulation in East Antarctica.

When the Antarctic and Greenland ice sheets are taken together, the largest estimates of the acceleration in their contribution to sea level (range from 0.112 to $0.140 \mathrm{~mm} \mathrm{year}^{-2}$ ) equal or exceed the acceleration in global mean sea level rise (GMSLR) calculated from the satellite altimeter sea level record $\left(0.099 \mathrm{~mm} \mathrm{year}^{-2}\right)$ [38], although we note that the ice sheet estimates (2003-2013) are only for the latter half of the satellite altimeter period (1993 to mid-2014), during which time the sea level acceleration may be larger. Wu and Heflin [39] also reported increased mass gain in land water storage and parts of East Antarctica, and decreased mass loss from glaciers in Alaska and some other regions such that the acceleration in the ocean mass gain is consistent with the satellite altimeter record.

\section{The Sea Level Budget}

Sea level estimates from satellite altimetry, GRACE observations of ocean mass, and Argo observations of thermal expansion of the upper $2000 \mathrm{~m}$ of the ocean combine to close the sea level budget since 2005 within uncertainties (see recent updates by Leuliette [57] and Yi et al. [36]). There have not yet been any new comprehensive attempts to close the budget since 1993 with the revised satellite altimeter data, nor have there been any new assessments of the budget of GMSL rise before the satellite altimeter period. Hay et al. [17] suggested that their lower rate of twentieth century GMSL rise is more consistent than earlier reconstructions with the sum of contributions. We note that there are several possible combinations of the contributions presented by Gregory et al. [83] that could match the reconstruction of Hay et al. Moreover, their estimated rate of sea level rise prior to 1950 is slightly larger than that of Church and White [18]. The small changes in the average of the updated estimates of the glacier contribution from Marzion et al. (2015) are unlikely to have a major impact on closure of the sea level budget for any of the periods considered.

\section{Attribution of Sea Level Change}

Based on the understanding of physical processes and results from climate models, the AR5 assessed the causes of observed changes in the primary components that contribute to GMSL change [84]. Advances in observations and understanding of changes in global ocean heat content since the AR4 led them to conclude that it is very likely that there has been a substantial contribution from anthropogenic forcing since the 1970s, which has thus contributed to thermosteric sea level rise. For land ice, Bindoff et al. [84] concluded that it is likely that anthropogenic forcing has contributed to mass loss of glaciers 
since the 1960s and surface melting of the Greenland ice sheet since 1993. Based on the assessment of the components, Bindoff et al. [84] concluded that it is very likely that there is a substantial contribution from anthropogenic forcing to GMSL rise since the 1970s. On the other hand, there was too little evidence available to attribute the causes of the observed mass loss from the Antarctic ice sheet since 1993.

Since the AR5, several new studies have quantified the contribution of anthropogenic forcing to changes in the thermosteric and glacier sea level components, which have been the largest contributors to GMSL rise since 1900 [5,83]. Marcos and Amores [85] compared the global thermosteric rise derived from observations of ocean temperature between 0 and $700 \mathrm{~m}$ to results derived from the CMIP5 experiments associated with "natural" (solar and volcanic) and "historical-only" forcings, where the latter include forcing from anthropogenic greenhouse gases and aerosols. For each of the two sets of experiments, they used a signal-to-noise maximizing empirical orthogonal function analysis to separate the signal that is a result of the forcing from the internal variability of the system. This forced response was projected on to the observations to compute the fraction of variability associated with the forced response. On this basis, they find that $87 \%$ (range of 72 to $100 \%$ ) of the observed thermosteric sea level rise since 1970 is associated with anthropogenic forcing.

Slangen et al. [86] compared observed estimates of thermosteric sea level rise from 1957 to 2005 over the full depth of the ocean to CMIP5 experiments forced by five different scenarios, including the natural and historical forcing used by Marcos and Amores [85] as well as anthropogeniconly, greenhouse gas-only, and anthropogenic aerosol-only forcings (Fig. 1). They find that the best agreement between the observed and modeled thermosteric sea level change is with the experiments that include all anthropogenic forcings, indicating a substantial anthropogenic influence on the observed period of sea level change. The addition of natural forcing that accounts for externally forced variability in the historical experiment improves the agreement on decadal time scales. Based on multiple regression analyses of observed temperature changes onto the simulated responses to the various forcings, Slangen et al. [86] derived the scaling factors $\left(\beta_{\text {est }}\right)$ by which the simulated responses must be multiplied to obtain the best fit to the observations. These indicate that the modeled anthropogenic response $\left(\beta_{\text {est }}=1.08 \pm 0.13\right)$ and a reduced modeled natural-only response $\left(\beta_{\text {est }}=0.70 \pm 0.30\right)$ fit the observations best, similar to what was found in attribution studies of global mean surface temperature [84].

Marzeion et al. [87] simulated changes in global glacier SMB since 1851 using a calibrated glacier model forced by the climatology from the natural and historical CMIP5 experiments and compared these with observations of global glacier SMB since 1960. Although the natural forcing causes negative SMB over the full-modeled period, the simulated SMB is too positive compared to the observations since 1991. In contrast, the SMB simulated by the historical forcing is consistent with the observations for the full period, accounting for an increasing percentage of the total mass loss that reaches $69 \pm$ $24 \%$ since 1991. The additional contribution to GMSL from the anthropogenic influence is $\sim 35 \mathrm{~mm}$, with most of this coming in recent decades.

In summary, the first formal detection studies for ocean thermal expansion and glacier mass loss since the AR5 was published have confirmed the AR5 finding of a significant anthropogenic contribution to sea level rise over the last 50 years.

\section{Glacier and Ice Sheet Projections}

\section{Glaciers}

The AR5 projected twenty-first century changes in global glacier SMB (except for Antarctic glaciers) from CMIP5 global mean surface air-temperature projections using a parameterized scheme derived from the results of four published glacier models, with each glacier model given equal weight in the projections [88]. Each of the glacier models includes detailed treatments of SMB and the evolution of glacier hypsometry. Projected glacier mass losses for 2100 outside Antarctica suggest a likely contribution of 0.05 to $0.17 \mathrm{~m}$ of sea level equivalent (SLE) under RCP2.6, corresponding to loss of 15 to $55 \%$ of present glacier volume, and 0.10 to $0.26 \mathrm{~m} \mathrm{SLE} \mathrm{under}$ RCP8.5, or 35 to $85 \%$ [5].

Two new studies have examined regional changes in glacier mass over the twenty-firs century. Clarke et al. [89] modeled glacier mass loss by 2100 for western Canada. They used Atmosphere-Ocean Global Circulation Models (AOGCM) projections for the four RCP scenarios to force a regional glacier model that includes $\mathrm{SMB}$ and, for the first time, a detailed physics-based model of ice dynamics that better represents changes in glacier hypsometry. Sensitivity tests of the model excluding ice dynamics show that icevolume loss is systematically underestimated. Model projections for 2100 suggest that, relative to 2005, western Canada glaciers will lose $\sim 60 \%$ of their volume for RCP2.6 and $\sim 80 \%$ for RCP8.5, as compared to model results from Marzeion et al. [90], which suggest $\sim 80 \%$ mass loss for RCP2.6 and $100 \%$ for RCP8.5, amounting to a difference of $<1 \mathrm{~mm}$ GMSL. Marzeion et al. [91] noted that other twenty-first century projections similarly showed relatively small differences in glacier mass loss under large differences in forcing scenarios, and concluded that these small differences are because the twenty-first century response is dominated by the response to climate change during the previous century (i.e., committed glacier loss to previous warming) as well as the effect of hypsometric changes that reduce glacier 

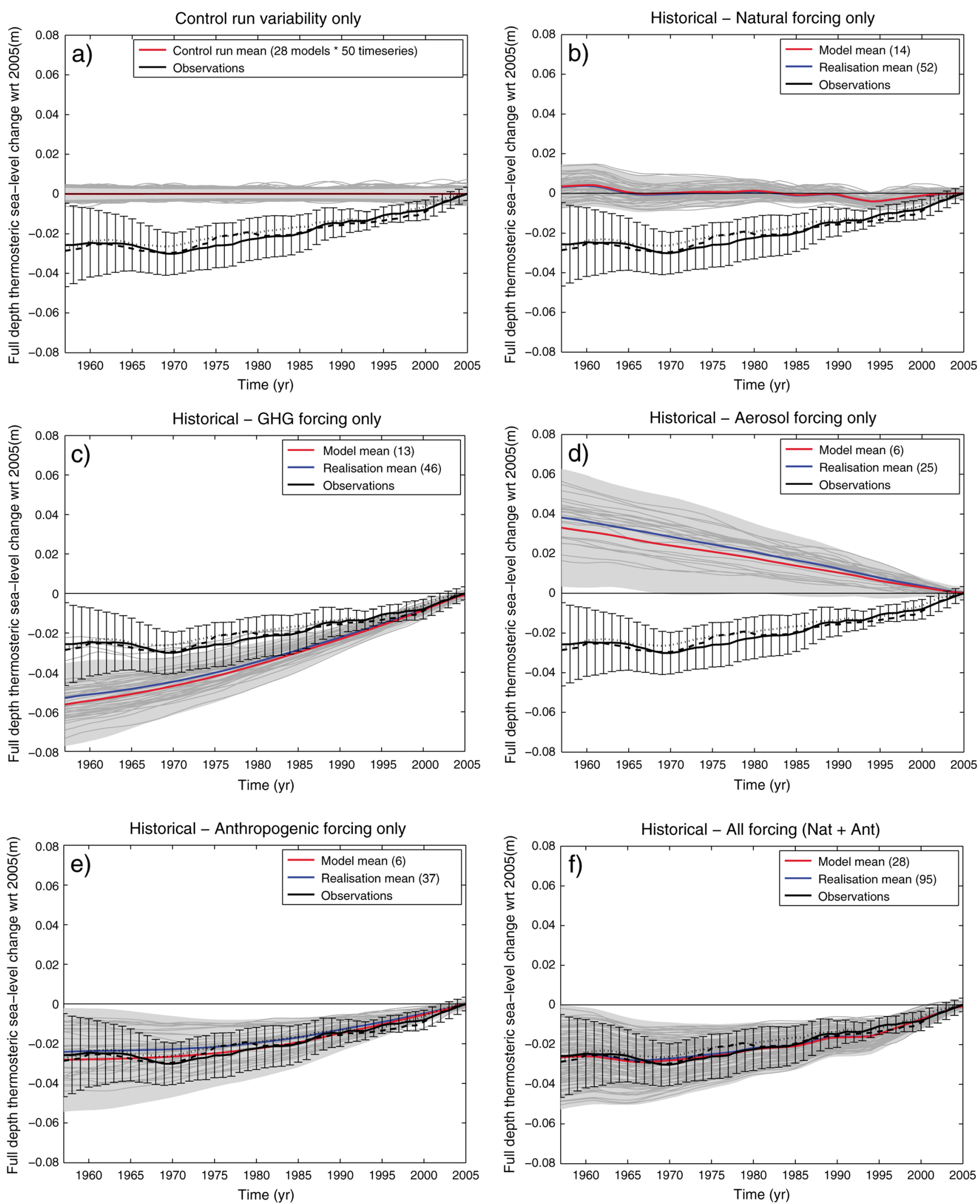

Fig. 1 Thermosteric global mean sea level change $(\mathrm{m})$ with respect to 2005. CMIP5 multimodel mean (red) $\pm 2 \sigma$ (light gray), realization mean (blue), individual realizations (dark gray). Numbers of models/ realizations in brackets. Observations (black lines): Domingues (solid +

uncertainties), Levitus (dashes), Ishii (dots). a Internal variability. b Natural forcing only. c Greenhouse gas forcing only. d Aerosol forcing only. e Anthropogenic forcing only. f All forcings combined. (From [86]) 
sensitivity to the forcing as the glaciers decrease in size and retreat to higher elevations.

Lang et al. [92] used a regional climate model coupled to a surface energy balance model to calculate changes in SMB of glaciers in Svalbard under RCP8.5. Their modeled domain is based on a fixed topography, and thus does not capture changes in glacier elevation and hypsometry that can significantly influence rates of mass loss [91]. By 2100, they find that the accumulation area of all glacierized areas in Svalbard will disappear, with a contribution of $\sim 7 \mathrm{~mm}$ SLE corresponding to a loss of $31 \%$ of present volume. This contribution is $\sim 25-$ $50 \%$ of previous estimates [90,93], with the large differences suggested to reflect the lower resolution climate models and more simplified SMB models used in the earlier studies.

In summary, new studies of glacier loss from two regions suggest contributions to GMSL rise that is less than studies assessed by the AR5 that included simulations from these regions (e.g., [90]). Because the AR5 did not provide regional estimates, it is not possible to make direct comparisons to these regional studies. Additional regional studies are required to further assess whether there are broader implications of these results.

\section{Greenland Ice Sheet}

The Greenland ice sheet loses mass through a combination of changes in SMB and dynamical changes associated with discharge into the ocean, including enhanced basal sliding, and the interaction between SMB and ice flow. The AR5 included both of these components in projections for the twenty-first century. Projections of SMB were made based on a relation between mass loss and temperature derived from regional climate modeling forced with CMIP5 AOGCMs [94], with additional allowances for methodological uncertainties and changes in ice sheet topography [88]. Projections of rapid change in discharge were based largely on flowline modeling of four of the larger outlet glaciers, with results scaled up by $\sim 5$ times because these glaciers drain $\sim 20 \%$ of the ice sheet by area [95], giving likely ranges of 0.02 to $0.09 \mathrm{~m}$ by 2100 for RCP8.5, and 0.01 to $0.06 \mathrm{~m}$ for the three RCPs of lower forcing, for which there was insufficient information to assess scenario dependence [88]. Likely ranges for projections of the total contributions to GMSL rise by 2100 relative to 1986 2005 range from 0.04 to $0.12 \mathrm{~m}$ for RCP2.6 to 0.09 to $0.28 \mathrm{~m}$ for RCP8.5 [88]. In general, the contributions from SMB and dynamics were assessed as nearly equal for each scenario except RCP8.5, where SMB is greater.

Since the AR5, several studies that documented large spatial and temporal variability in discharge of outlet glaciers (section "Greenland Ice Sheet") suggest that a simple extrapolation and scaling of a few of the largest glaciers for projections may be inaccurate. Csatho et al. [67] found that mass loss is not proportional to the drainage basin area, and that the majority of Greenland mass loss during the 2003-2009 period ( $\sim 80 \%$ ) was due to thinning of small to moderately sized drainage basins rather than the four large glaciers modeled by Nick et al. [95]. In contrast, Enderlin et al. [69] found that these four glaciers represented $42 \%$ of the ice sheet discharge change from 2000 to 2012 as opposed to the $20 \%$ expected from an assumption of proportionality with drainage area. Based on assumptions about regional variations in discharge through the twenty-first century, Enderlin et al. [69] estimated a contribution to GMSL rise of $80 \mathrm{~mm}$, similar to the upper limit of the AR5 likely range for the RCP8.5 scenario (85 mm).

A number of studies have documented rapid drainage of supraglacial lakes to the base of the ice sheet through conduits, confirming earlier studies that suggested that such drainage increases the rate of short-term ice motion by basal sliding [96,97]. Leeson et al. [98] showed that the area over which supraglacial lakes are distributed will increase by $\sim 50 \%$ by 2060 under RCP 8.5 . However, studies since the AR5 support the conclusion that enhanced basal lubrication makes an insignificant contribution to the likely range of sea level rise over the twenty-first century. Some studies suggested that this occurs through the subglacial drainage system becoming more efficient with increased discharge, thus reducing basal sliding $[99,100]$. Mayaud et al. [101] forced a subglacial hydrological model of the western ice sheet margin in the Paakitsoq region with surface runoff that was derived from climate model output for the RCP2.6, 4.5, and 8.5 scenarios. They showed that as runoff increases in response to a warmer climate, the subglacial drainage system transitions from a less efficient network with associated higher basal sliding to a more efficient network with an associated reduction in basal sliding. Shannon et al. [102] used four ice sheet models forced by a regional climate model under the A1B scenario to examine the contributions of changes in SMB and of outflow associated with enhanced basal sliding. Enhanced basal sliding was represented by a set of parameterizations that encompasses the range of observations of annual runoff and increase in basal ice flow. Experiments for changes in SMB only find a contribution to GMSL rise by 2100 ranging from 47.5 to $61 \mathrm{~mm}$, lying within the AR5 likely range of 30 to $150 \mathrm{~mm}$ for the same scenario [88]. Shannon et al. [102] found that the contribution from basal sliding remains below $\sim 5 \%$ of the contribution from SMB.

The AR5 assessed the positive feedback between SMB and ice sheet height as contributing 0 to $15 \%$ of SMB change over the course of the twenty-first century. Based on climate projections under the A1B scenario used to force five ice sheet models, Edwards et al. [103] found that the SMBelevation feedback accounts for an additional 1.8-6.9 \% (95\% confidence interval) sea level rise by 2100 , in agreement with the AR5. 
Fürst et al. [104] forced an ice sheet model that accounts for basal lubrication and ocean thermal forcing of ice discharge with reanalysis data over the period 2005-2010. The consequent mass loss, of which $40 \%$ is from ice discharge, contributes $0.62 \mathrm{~mm}$ year $^{-1}$ to GMSL rise, similar to observations (section "Greenland Ice Sheet"), giving confidence in the ice sheet model. With forcing from an ensemble of ten CMIP5 AOGCMs under the four RCP scenarios, Fürst et al. [104] found the contributions to GMSL rise by 2100 relative to 2000 range from $0.04 \pm 0.02 \mathrm{~m}$ ( 1 std. dev.) for RCP2.6 to $0.10 \pm 0.03 \mathrm{~m}$ for RCP8.5, which are in good agreement with the AR5 likely ranges. Of this mass loss, the contribution from SMB dominates, with discharge decreasing by 2100 as the margin thins and retreats from the coast; enhanced basal lubrication accounts for less than $1 \%$ of the discharge.

In summary, projections of Greenland mass loss support the AR5 assessment that enhanced basal lubrication will make an insignificant contribution sea level rise over the twenty-first century. Projections of mass loss from discharge and SMB fall within the AR5 likely ranges, but differ from the AR5 in suggesting a greater contribution from SMB, with decreasing discharge associated with the ice sheet margin retreating from the coast.

\section{Antarctic Ice Sheet}

The AR5 projected the contribution to GMSL from the Antarctic ice sheet for changes in SMB (primarily changes in snow accumulation) and outflow across the grounding line to floating ice shelves. In the latter case, mass is subsequently lost in roughly equal amounts by calving and marine melt from the lower ice surface (Rignot et al. [105]. Projections of the combined (SMB and outflow) contribution to GMSL by 2100 relative to $1986-2005$ were assessed to fall in a likely range of -0.04 to $0.16 \mathrm{~m}$ for RCP2. 6 and -0.08 to $0.14 \mathrm{~m}$ for RCP8.5 [88]. Projections of the outflow contribution to GMSL by 2100 were assessed to fall in a likely range of -0.02 to $0.185 \mathrm{~m}$, with no scenario dependence specified due to insufficient information. The assessed contribution from a potential marine ice sheet instability (MISI) (section "Antarctic Ice Sheet") lay outside the likely range of the outflow contribution and was characterized by a magnitude of an additional several tens of centimeters [5].

Studies published since the AR5 can be divided into three groups: those for Pine Island Glacier (PIG) and the other glaciers of the Amundsen Sea Embayment (ASE); studies of the whole of the West Antarctic ice sheet (WAIS) and individual East Antarctic glaciers; and studies of the whole of Antarctica.

Favier et al. [79] reported a comparison of three models of the PIG's evolution over 50 years in response to a step change in melt starting from a situation similar to the present day. They obtained a three- to six fold increase in the rate of mass loss compared to the present-day observations with GMSL contributions in the range of 9 to $25 \mathrm{~mm}$ over 50 years. Further experiments in which the initial change in melt is removed suggested that PIG's current retreat may be irreversible. In similar experiments, Seroussi et al. [106] found GMSL contributions of up to $20 \mathrm{~mm}$ in 50 years. Both papers are consistent with the AR5 assessment that PIG's end-of-thecentury contribution can be characterized by centimeters of GMSL rise, and lie well within the AR5 assessment of the likely contribution from Antarctic rapid ice dynamical change (Table 1) [5].

At the time of the AR5, there was no evidence of grounding-line retreat for PIG's larger neighbor Thwaites Glacier (TG). Subsequent research has shown, however, that retreat in other parts of the ASE (most notably TG) is just as pronounced as for PIG [78]. Joughin et al. [80] simulated the consequences of this retreat and found a moderate contribution to GMSL over a century of $<0.25 \mathrm{~mm}_{\text {year }}{ }^{-1}$ (similar to PIG's assessed contribution) with larger rates $\left(>1 \mathrm{~mm}\right.$ year $\left.^{-1}\right)$ predicted as the grounding line retreats on to deeper bedrock after 200 to 900 years.

Cornford et al. [109] simulated the response of the WAIS to both atmospheric and oceanic forcing derived from regional models that were forced, in turn, by climate models for the A1B and E1 (strong mitigation) scenarios (Fig. 2). In particular, the oceanic forcing includes the influx of warm water
Table 1 Projections of mass loss by rapid ice-sheet dynamics from the Antarctic ice sheet for the twenty-first century

\begin{tabular}{llll}
\hline Reference & Region of ice sheet & Mass loss (m) & Period \\
\hline AR5 & all of Antarctica & -0.020 to 0.185 & $1996-2100$ \\
Favier et al. [79] & PIG & 0.009 to 0.025 & $2000-2050$ \\
Seroussi et al. [106] & PIG & up to 0.020 & $2000-2050$ \\
Joughin et al. [80] & TG & up to 0.025 & $2000-2100$ \\
Gong et al. [107] & Lambert & up to 0.009 & $2000-2100$ \\
Sun et al. [108] & Totten & up to 0.020 & $2000-2100$ \\
Cornford et al. [109] & WAIS & up to 0.200 & $2000-2100$ \\
Levermann et al. [110] & all of Antarctica (RCP2.6) & 0.02 to 0.140 & $2000-2100$ \\
Levermann et al. [110] & all of Antarctica (RCP8.5) & 0.04 to 0.210 & $2000-2100$ \\
\hline
\end{tabular}


Fig. 2 Net change in volume above flotation in the WAIS over the course of the combined experiment in of both atmospheric and oceanic forcing derived from regional models that were forced, in turn, using climate models for the A1B and E1 (strong mitigation) scenarios. Only the Amundsen Sea Embayment experiences a net loss $(\Delta V)$ in all of the combined experiments. Nonetheless, the result is a net loss over West Antarctica as a whole. Note that Thwaites glacier does not retreat in the combined anomaly experiments (which use the synthetic accumulation), and the ASE could contribute an extra $9 \times$ $10^{3} \mathrm{~km}^{3}$ loss by 2100 and $40 \times$ $10^{3} \mathrm{~km}^{3}$ by 2200 . (From [109])

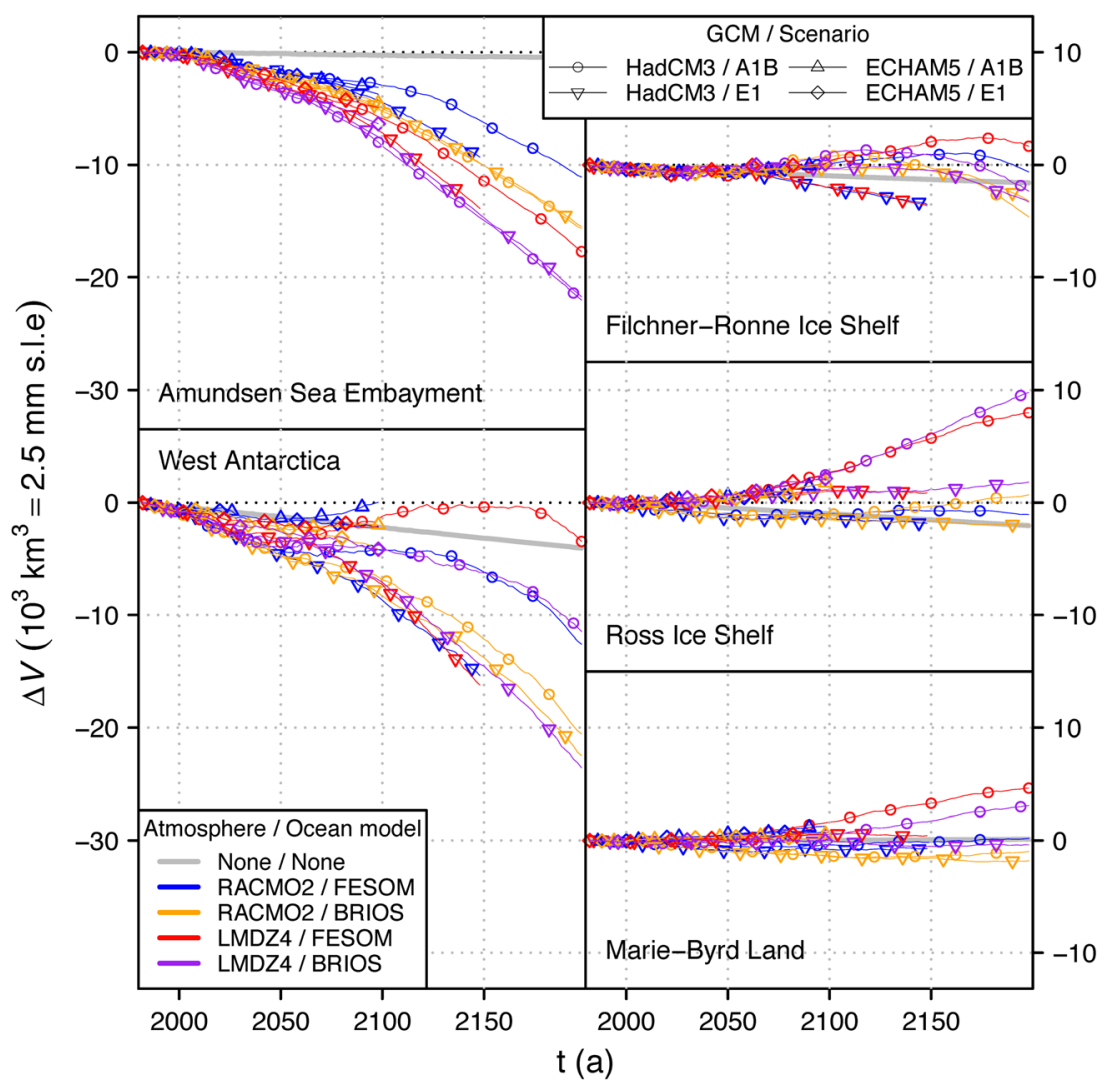

under the Filchner-Ronne ice shelf reported by Hellmer et al. [111], although this only occurs towards the end of the current century. Substantial mass loss is therefore dominated by the ASE and contributes up to $50 \mathrm{~mm}$ GMSL by 2100 , including a contribution from the retreat of TG. Increased outflow is compensated by an increase in SMB, particularly for the Filchner-Ronne sector. This compensation is, however, weaker in the E1 scenario, producing the surprising result that the contribution to GMSL is larger in this mitigation scenario than in A1B. This results from the contributions from outflow (oceanic forcing) and SMB being independent, with the latter responding to greenhouse forcing. The compensation term (additional outflow between 0 and $35 \%$ of SMB) employed by the AR5 may therefore over estimate this effect and hence exaggerate the contribution to GMSL rise. Finally, more extreme scenarios, in which melt rate is increased across all ice shelves from 1980 (at odds with the regional modeling results and observations), produce contributions of up to $200 \mathrm{~mm}$ by 2100 (Table 1). In more idealized modeling, Wright et al. [112] identify Institute and Moller ice streams draining into the Filchner-Ronne ice shelf as close to the threshold for retreat, albeit on a millennial timescale, with associated contributions of $\sim 0.14 \mathrm{~m}$ to GMSL over this timescale.

Gong et al. [107] used a similar methodology to Cornford et al. [109] for the Lambert Glacier and found that increased outflow is more than compensated by increased SMB, and that only loss of the Amery ice shelf (for instance by large- scale crevassing, see the following section) leads to GMSL rise (up to $9 \mathrm{~mm}$ by 2100 depending on the area lost). Sun et al. [108] also used similar methods and obtain a contribution from Totten Glacier, East Antarctica, of no more than $20 \mathrm{~mm}$ by the end of the century.

Pollard et al. [113] investigated the consequences of crevasse-based loss of the large ice shelves followed (in their model) by the collapse of the ice cliffs left at grounding lines, resulting in large contributions to GMSL of the order of ten meters per millennium (10 $\mathrm{mm}_{\text {year }}{ }^{-1}$ ). Kuipers Munneke et al. [114] used a model of firn densification to assess the probability of meltwater ponding on Antarctica's ice shelves in the future, which may then lead to their destabilization through large-scale crevassing such as caused the collapse of the Larsen B ice shelf [115]. However, they found this effect would not be important outside of the Antarctic Peninsula during the present century, in accord with the assessment by the AR5.

Levermann et al. [110] developed a probabilistic approach to projecting the contribution of Antarctica to GMSL by employing linear response functions based on the response of three ice sheet models from the SEARISE exercise [116] to an idealized step increase in marine melt. A scaling is developed between global mean temperature change and ocean temperatures around Antarctica based on the CMIP5 ensemble, which combined with the response functions forms a probabilistic framework for making projections. The approach 
successfully reproduces the observed contribution between 1992 and 2001, provided a suitable delay between global mean and regional ocean temperatures is used. With this delay, $66 \%$ probability ranges of end-of-the-century GMSL change are $0.02-0.14 \mathrm{~m}$ for RCP2.6 and $0.04-0.21 \mathrm{~m}$ for RCP8.5. These ranges are broadly similar to the AR5 assessed likely range ( -0.02 to $0.185 \mathrm{~m}$ ), for which scenario dependence was not assessed, but the upper end for RCP8.5 is slightly higher. A potential contributing factor to the slightly larger range may be the retreat patterns displayed the SEARISE models, which in some cases are fairly extensive.

In summary, new studies suggest that a MISI may have been initiated in parts of the WAIS, but that only a few WAIS ice streams will experience MISI during the twentyfirst century. New projections of mass loss from the Greenland and Antarctic Ice Sheets by 2100 , including a MISI contribution from parts of WAIS, suggest a contribution that falls largely within the likely range (i.e., two thirds probability) of the AR5. These new results increase confidence in the AR5 likely range, indicating that there is a greater probability that sea level rise by 2100 will fall in that range with a corresponding decrease in the likelihood of an additional contribution of several tens of centimeters above the likely range.

\section{Projections of Global Mean Sea Level Rise by 2100}

The AR5 assessed two categories of models used for projections of twenty-first century sea level rise: process-based models that simulate the underlying processes and interactions, and semi-empirical models (SEMs) that are based on statistical relationships between observed GMSL and global mean temperature or total radiative forcing (RF) [5]. The AR5 assigned medium confidence to process-based projections, due to (i) understanding of the modeled physical processes, (ii) the consistency of the models with wider physical understanding of those processes as elements of the climate system, (iii) the consistency of modeled and observed contributions, and (iv) the consistency of observed and modeled GMSL. As discussed at length in the AR5, SEM projections are based on the assumption that future sea level change will have the same relationship to global mean temperature change or RF as it had in the period of calibration. This assumption implies uncertainty that is difficult to quantify. Consequently, there is low agreement and no consensus in the scientific community about their reliability, giving one reason for which they were assigned low confidence by the AR5. The other is that, in nearly every case, SEMs projected a substantially higher sea level by 2100 than the process-based models, but no satisfactory physical explanation was available for this. To date, there have been no new projections of sea level using revised estimates of sea level to train semi-empirical models. Orlic and Pasaric [117] analyzed three variants of semi-empirical models and showed that the projections are similar through the middle of the twenty-first century but diverge after that and urge caution in their use beyond the twenty-first century.

On the basis of their higher assessed confidence, the AR5 projections for the twenty-first century are based on processbased models [5]. For RCP2.6, the likely range of sea level rise by 2100 is 0.28 to $0.61 \mathrm{~m}$. For RCP8.5, the likely range by 2100 is 0.52 to $0.98 \mathrm{~m}$ with a rate during $2081-2100$ of 8 to $16 \mathrm{~mm} \mathrm{year}^{-1}$. Church et al. [5] concluded that "there is currently insufficient evidence to evaluate the probability of specific levels above the assessed likely range" (p. 1140), but that sea levels substantially higher than the likely range would only occur in the twenty-first century if the marine-based sections of the Antarctic ice sheet were to collapse. The potential contribution could not be precisely quantified, but they determined with medium confidence that "this additional contribution would not exceed several tenths of a meter of sea-level rise during the 21st century" (p. 1140).

Three studies since the AR5 have made projections for twenty-first century GMSL rise based on some level of expert elicitation. Horton et al. [118] presented projections of GMSL rise based on a survey involving 90 individuals with some experience in publishing on sea level. The respondents estimated $66 \%$ confidence intervals for GMSL rise by 2100 , with respect to the time-mean of 1986 to 2005 . Their median estimate of the likely range was 0.7 to $1.2 \mathrm{~m}$ for scenario RCP8.5; they noted that their range lies above the AR5 likely range of 0.52 to $0.98 \mathrm{~m}$. They also reported a very likely range of 0.5 to $1.5 \mathrm{~m}$ for RCP8.5. In commenting on Horton et al., Gregory et al. [119] suggested that some respondents might have assumed an extensive Antarctic marine ice sheet instability to lie within the likely range of possibilities. According to the AR5, a MISI is unlikely to occur, but if initiated, it could add up to several tenths of a meter to GMSL rise during the twenty-first century, making the AR5 and Horton et al. consistent. However, as discussed in section "Antarctic Ice Sheet" the several detailed ice sheet modeling studies that have been published since the AR5 suggest a contribution from Antarctic ice sheet rapid dynamical change, including the possibility of MISI, that falls largely within the AR5 likely range, with only one estimate being higher, by $0.025 \mathrm{~m}$, or one tenth of the difference $(0.22 \mathrm{~m})$ between the upper estimates of the likely range by the AR5 and Horton et al.

Kopp et al. [120] combined results from process-based models and expert elicitation to derive projections of twentyfirst century GMSL rise from each of the main components, which were then summed to derive the total rise. For the ice sheets, they reconciled the scenario differences between the AR5 projections and those from the expert elicitation by using the AR5 to characterize the median and likely ranges and expert elicitation to calibrate the shape of the tails. They used results from a single glacier model [90], one of four considered by the AR5, that by itself has a narrower likely range than 
in the AR5, results from a selection of CMIP5 GCMs that give a higher and wider likely range than in the AR5, and a relationship between changes in land water storage and population that was not considered by the AR5 with the likely range falling within the AR5 likely range. Despite these differences, Kopp et al. [120] derive a similar median $(0.79 \mathrm{~m})$ and likely range $(0.60$ to $1.00 \mathrm{~m})$ for the total GMSL rise for the RCP8.5 scenario as in the AR5. In addition, when including the results from the expert elicitation, they estimated a very likely range of 0.52 to $1.21 \mathrm{~m}$, and a virtually certain range (99\% probability) of 0.39 to $1.76 \mathrm{~m}$.

Jevrejeva et al. [121] combined the uncertainty estimates from the AR5 results for thermosteric, glacier, and land water storage for the RCP8.5 scenario with results from an assessment on contributions from ice sheet dynamics by 13 experts [122] to derive a probability distribution function (PDF) for twenty-first century GMSL rise. The main difference between the ice sheet contributions lies in the shape assumed for the uncertainty distribution. The AR5 assumed it to be uniform within the likely range from the AR5; Jevrejeva et al. used the positively skewed distribution from the expert elicitation, which had a long tail extending towards the high end, dominated by Antarctica and reflecting the wide spread and thus lack of consensus among the expert estimates [122]. Consequently, their combined PDF for GMSL rise is positively skewed by the Antarctic contribution, and their median and likely range are 0.79 [0.58 to 1.20$] \mathrm{m}$, to be compared with $0.74 \mathrm{~m}[0.52$ to 0.98$] \mathrm{m}$ in the AR5. Jevrejeva et al. [121] report a very likely range of 0.45 to $1.80 \mathrm{~m}$. These latter values are significantly larger than Kopp et al. and Horton et al. and inconsistent with recent results on simulation of the Antarctic ice sheet contributions using state of the art models discussed in Section 6c.

In summary, the three studies of projections of twenty-first century GMSL rise published since the AR5 all depend on results from expert elicitation. Jevrejeva et al. [121] and Kopp et al. [120] used them to help characterize the tails of the distribution about the likely range derived from processbased models, providing a means to infer ranges for higher probabilities, whereas Horton et al. [118] relied entirely on them to characterize the likely range. We have low confidence in conclusions based on expert elicitation because, as noted by Gregory et al. [119], the respondents are not asked to justify, and we cannot know how they arrived at their conclusions. Although the physical processes have operated in the past, to our knowledge, the circumstances of anthropogenic forcing are entirely unprecedented in recent Earth history. In these circumstances, intuition should not be trusted, because there is no relevant experience in which it could have been trained to make the right decision, and we believe that the only rational approach to quantitative assessment is by transparent reasoned analysis of available results. For instance, Fig. 2 of Horton et al. shows that several of the respondents placed the 83 percentile for GMSLR by 2100 for RCP 8.5 above $2.5 \mathrm{~m}$, i.e., more than $1.5 \mathrm{~m}$ above the AR5 likely range, the largest estimate being at about $6 \mathrm{~m}$. No physically plausible scenarios for values above $2.5 \mathrm{~m}$ have been published in the peer-reviewed literature; on the contrary, it has been argued that they are physically untenable [123]. Furthermore, these projections are inconsistent with recent results on simulation of the Antarctic ice sheet contributions using state-of-the-art models (section "Glacier and Ice Sheet Projections").

\section{Regional Projections and Emergence Time of the Forced Signal}

GMSLR due to the increase in the volume of the global ocean affects relative sea level everywhere, but projected local regional sea level (RSL) change differs from GMSLR because of various effects, which we can put in five categories:

1. The ocean dynamic response (the change in the ocean dynamic topography) to the change in its 3-D density field (arising from temperature and salinity change) and circulation, caused by the effect of climate change on surface heat, freshwater, and momentum (wind stress) fluxes. Many studies consider the sum of ocean dynamic sea level change and the contribution of global steric change (thermal expansion) to GMSLR; we refer to this sum as "ocean climate change."

2. The GeLi effects, or fingerprints (section "The Satellite Altimeter Period") of land-ice change, on the geoid and the elastic response of the lithosphere.

3. Glacial isostatic adjustment (GIA), which is the ongoing change in the geopotential field and deformation of the solid Earth due to the reduction of ice sheet mass since the Last Glacial Maximum 20,000 years ago.

4. The redistribution of atmospheric mass, i.e., the change in mean sea level pressure. This term is shown in the AR5 and earlier to be small compared with other multidecadal changes.

5. Local tectonic effects, which are not discussed further here (see Kopp et al. [124] for a discussion).

The AR4 considered ocean dynamical change, but not GeLi effects, because it was not able to make a projection of rapid ice sheet dynamic change, and therefore could not produce estimates of regional sea level change due to all contributions. Subsequent advances (following Katsman et al. [125], Slangen et al. [126], and Church et al. [127]) enabled this to be done in the AR5, which therefore presented projections of RSL change including all the above-mentioned effects except tectonics, which were also excluded. A number of regional projections and projections at coastal tide gauge sites, building on the AR4 and AR5 assessments and using the AR5 
approach, have also been completed [120,128-135]. Slangen et al. [135] also made RSL projections including all effects based on CMIP5 simulations of ocean climate change, combined with somewhat different estimates for the land-ice contributions from the AR5 assessment. They pointed out that the distribution of RSL change is positively skewed (also seen in AR5, Fig. 13.22) because the GeLi effect of land-ice change is slightly positive in large low-latitude areas and strongly negative in small high-latitude areas near to the ice sheets and glaciers.

As in the AR5, Slangen et al. [135] projected RSL change of less than the global mean (by up to $50 \%$ ) near West Antarctica and Greenland, due to GeLi effects of the ice sheets. On the other hand, the AR5 and Slangen et al. [135] projected RSL rise exceeding the global mean (by more than $20 \%$ ) on the east coast of North America and in a roughly zonal band on the north side of the Antarctic Circumpolar Current. These phenomena are due to ocean climate change. They are commonly seen in AOGCMs and have previously been noted (e.g., AR4, Pardaens et al. [136]), but their magnitude differs greatly among models $[137,138]$. Bouttes and Gregory [139] provided evidence that the model spread in projected changes in ocean surface fluxes of momentum (wind stress), heat, and freshwater forcing all contribute to the model spread of projected ocean dynamic SL change.

Bouttes et al. [137] demonstrated that the north-south zonal dipole (positive ocean dynamical sea level rise to the north of the ACC and negative to the south) is largely a thermosteric effect caused by and roughly proportional to the change in the mid-latitude westerly winds in the Southern Ocean, which AOGCMs generally project to increase in magnitude and shift southward, consequently shifting and tilting the isopycnals in the ocean. Frankcombe et al. [140] reproduced this effect in an eddy-permitting ocean model (one fourth degree resolution). They pointed out that the same feature in RSL change can be seen in the altimeter trends since 1993 and could be due to anthropogenic influence (forced by greenhouse gases or ozone depletion) on the Southern Annular Mode [141,142]. It is possible that the effect of eddy saturation in eddyresolving models might reduce the effect, although Suzuki and Ishii [143] showed similar sea level change in eddypermitting and lower-resolution models. In CMIP5 models, Bouttes and Gregory [139] found that surface heat flux change also contributes to producing the feature, which is apparent in CMIP5 historical simulations as well as in projections, and in some regions it is already larger than simulated unforced trends of the length of the altimeter period, consistent with it being a response to anthropogenic forcing [144].

The enhanced RSL rise in the North Atlantic is also a part of dipole feature, with reduced RSL rise to the south, though its geographical detail is model dependent $[145,146]$. This feature has previously been associated with weakening of the Atlantic Meridional Overturning Circulation (AMOC) due to buoyancy forcing, and is caused by a change in surface heat flux (a reduction of heat loss in the North Atlantic in a warming climate) and increase of surface freshwater flux in CMIP5 models (Bouttes and Gregory [139]), as in earlier models. RSL rise in the north of the North Atlantic, whether due to heat or freshwater input, is mainly the direct result of the added buoyancy $[145,146]$, and the consequent weakening of the AMOC brings about a redistribution of heat which opposes the effect of the surface flux change on RSL in most of the affected area, but reinforces it along the east coast of North America [145], where the projected RSL rise is consequently particularly large [147]. Howard et al. [148] assessed the magnitude of the effects of increased freshwater inflow from ice sheet mass loss on ocean dynamic sea level change and the AMOC to be small compared with the effects of changing surface fluxes from the atmosphere.

The dominant feature of observed RSL change in the altimeter period is the contrast of rising sea level in the west and falling in the east in the Pacific, due to changes in wind stress forcing $[149,150]$. It has been argued that unforced variability associated with the Pacific Decadal Oscillation (PDO) [151-154] contributes to this pattern, although Frankcombe et al. [155] found that the relationship between the sea level pattern and the PDO is not statistically robust in short observational records. Hamlington et al. [152] removed the influence of PDO statistically, and isolated a remaining sea level pattern associated with warming in the western tropical Pacific, which they suggested could be due to anthropogenic warming of the tropical Indian Ocean. However, this residual sea level pattern was somewhat different to that found in [154] and may not be robust because of the short available satellite altimeter record (about half a PDO cycle), and Palanisamy et al. [156] also disputed this interpretation. The east-west Pacific pattern (Fig. 3) does not appear to be anthropogenic in CMIP5 historical simulations, but on the other hand, it is too large to be consistent with unforced variability as

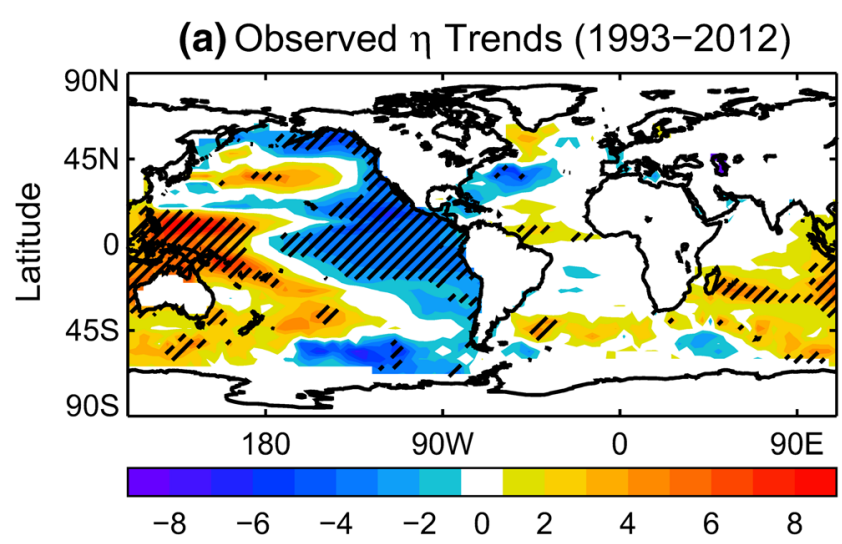

Fig. 3 Observed sea level change trends $\left(\mathrm{mm} \mathrm{year}^{-1}\right)$ from satellite altimetry between 1993 and 2012. The hatching indicates trends that are significant (at the $5 \%$ level) with respect to at least two thirds of CMIP5 pre-industrial control simulations. (From [144]) 
simulated by the AOGCMs [144,156,157]. Consequently, this remains an important phenomenon that still requires an explanation. It could also be associated with some of the explanations advanced for the hiatus of global warming [158-160].

Under a given future scenario, RSL change due to ocean climate change will be due to a combination of forced response and unforced variability of the climate system. The former grows with time, while the latter, although staying roughly constant [132], may be substantial. $\mathrm{Hu}$ and Deser [161] showed that even by the middle of this century, unforced variability leads to an uncertainty of up to a factor of two in coastal projections, the largest spread (in proportional terms) being on the north Pacific and north Atlantic coasts, despite the very small spread in projections of global mean thermal expansion. Bordbar et al. [162] found that even after 100 years, the spread in local projections due to unforced variability may be comparable to global thermal expansion.
The "time of emergence" is when the forced signal becomes discernible because it is sufficiently large compared with unforced variability [163]. Several recent studies have evaluated the time of emergence of sea level change, with various definitions, in the CMIP5 dataset. For ocean dynamical sea level change (which excludes GMSLR), the local signal is not detectable in the majority of the ocean even after 100 years of anthropogenic forcing [162,164] (Figs. 4 and 5). It only emerges clearly in the Southern Ocean near Antarctica, where projected sea level change is markedly less than the global average due to the north-south zonal dipole. A nonuniform pattern of change (i.e., contrasts between dynamic sea level change in different regions) should be detectable in only a few years, and indeed, already may be detected in the Southern Ocean [144].

If dynamical sea level change and thermal expansion are taken together (i.e., considering sea level change due to ocean
Fig. 4 Multimodel ensemble median time-of-emergence (ToE) for regional sea-level change under RCP8.5. Different change signals are used. a Ocean dynamic topography change (dynamic sea level). b Ocean climate change (dynamic sea level change plus global mean thermosteric sea level change). c Relative sea level change (total sea level change). Warm (cold) colors represent rising (falling) sea level; light gray areas have no emergence before 2080; deep gray color means no agreement among models; white color means no data coverage or over land. (From [164])
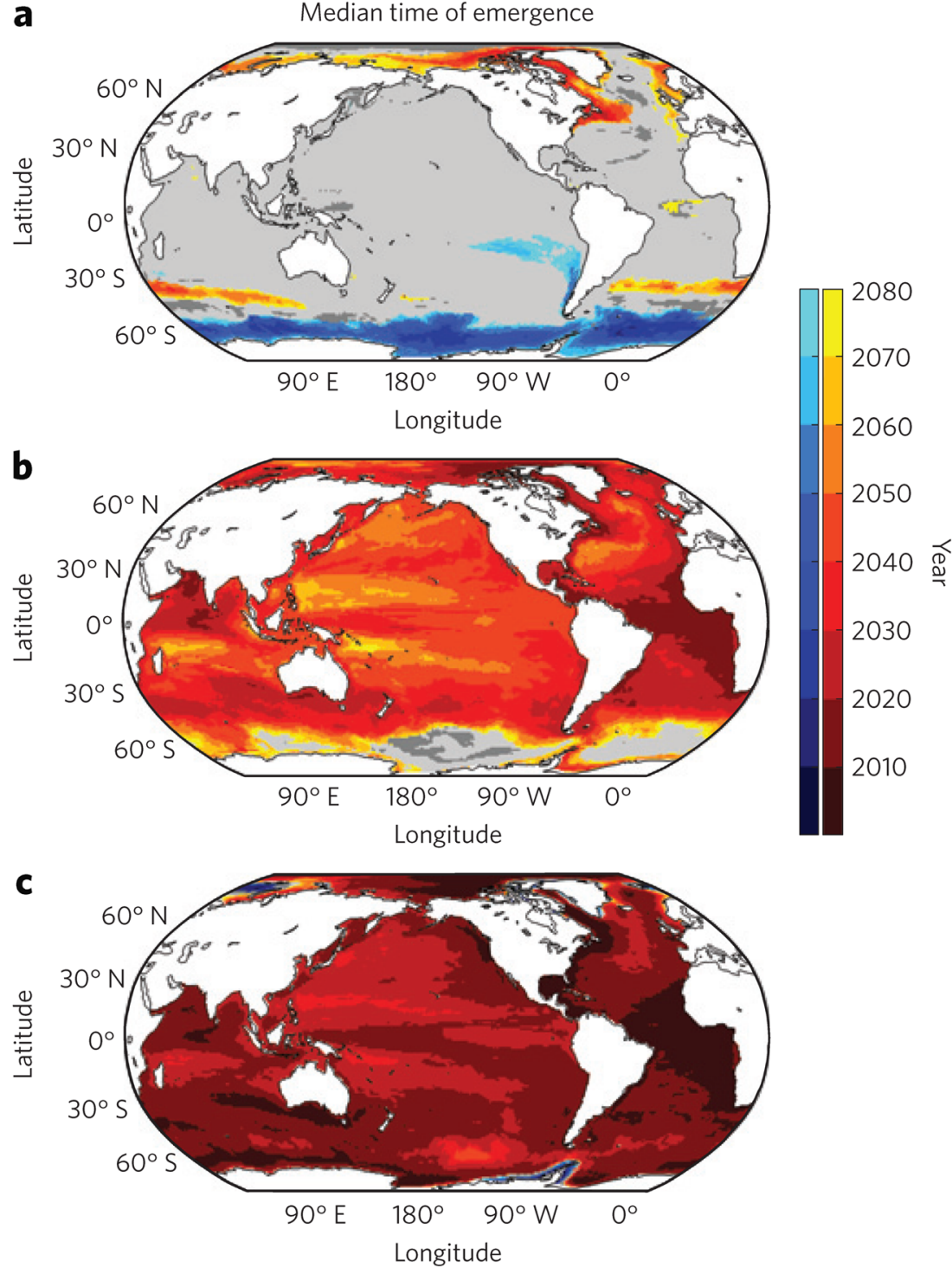


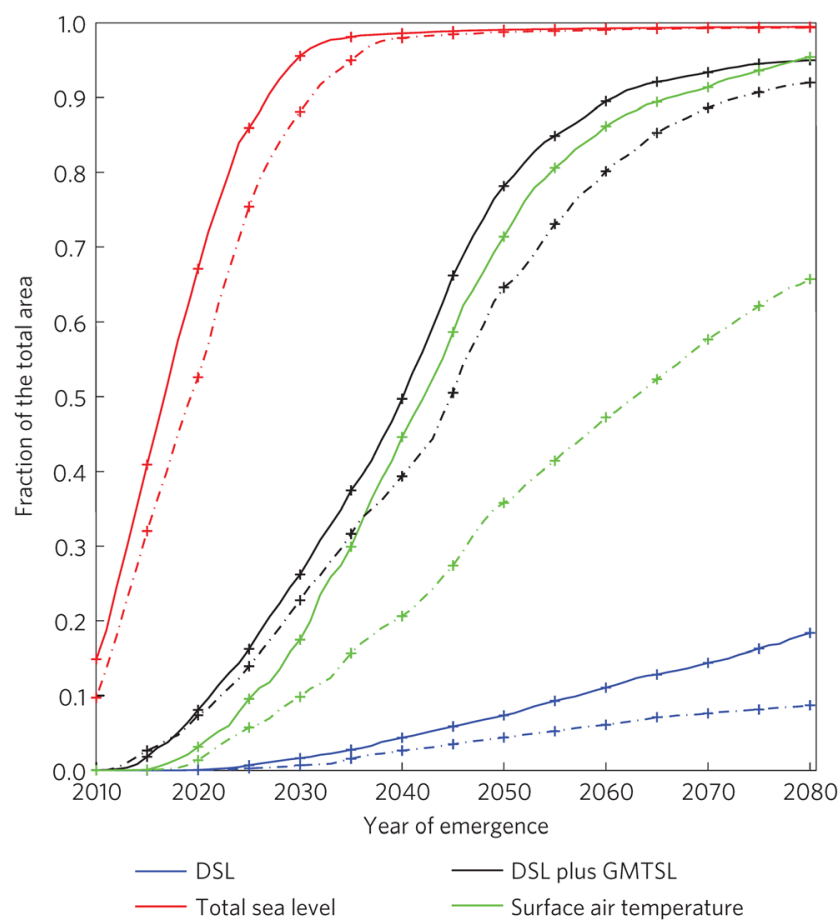

Fig. 5 The cumulative fraction of the total area with the emergence of change signals before the given time from the multimodel ensemble median patterns. Dynamic sea level (blue), ocean climate change (dynamic sea level plus global mean thermosteric sea level, black), relative sea level (total sea level, red), surface air temperature (green). Dash-dot lines are for RCP4.5 and solid lines for RCP8.5. (From [164])

climate change), the signal of forced sea level change relative to the reference mean level of 1986-2005 emerges in about half of the ocean area by 2040 [164] (Figs. 4 and 5). Instead of using a reference level, a comparison of trends in projections of forced sea level change starting in 1990 with simulated unforced trends of the same length shows a detectable signal by the early 2030s in half of the ocean area [165]. In the MPI-ESM-LR AOGCM, chosen as an example, trends of 20 years starting in 2006 exceed one standard deviation of unforced variability in more than half of the area, and trends of 50 years in more than $90 \%$ [157]. With both techniques, the region of earliest emergence is the low-latitude Atlantic, where unforced variability is particularly small $[132,144,157,164,165]$. Early emergence is also noted in some coastal areas, especially the Atlantic coast of North America [157,165]. By contrast, in much the Southern Ocean, where variability is high and the forced response is small, the signal of change may not be detectable until late in the twenty-first century or afterwards $[144,164,165]$. If RSL including all contributions to GMSLR (not just thermal expansion) and GeLi effects is considered, the signal of forced change is discernible in about half of the ocean area as early as 2020 [164] (Figs. 4 and 5).

In CMIP5 models, the patterns of predicted sea level change due to ocean climate change (Fig. 6) are stable in time and fairly independent of scenario [144]. Consequently, accurate projections can be made by scaling a fixed pattern with a time-dependent magnitude, as for surface air temperature, but ocean volume-mean temperature is generally a slightly more accurate predictor than global mean surface air temperature for scaling the pattern of sea level change. Recent work has begun to explore the impact of individual radiative forcings (greenhouse gases, aerosols, and natural forcing) on historical sea level change [166].

In summary, there has been new work in three main areas since the AR5. First, analysis of models indicates that the two commonly predicted features of future regional sea level change, namely the increasing tilt across the ACC and the dipole in the North Atlantic (both with enhanced sea level rise on their northern side), are related to regional changes in wind stress and surface heat flux. Much remains to be understood about the geographical patterns and remote influences of surface flux changes, and their effects on ocean circulation and interior transports, in order to make confident regional projections. Second, it is expected that sea level change in response to anthropogenic forcing in regions of relatively low unforced variability, such as the low-latitude Atlantic, will be detectable within 20 years or less. We note that an anthropogenic influence has already been detected on the global mean (section "Attribution of Sea Level Change"). Third, the east-west contrast in the Pacific of sea level trends observed since the early 1990s cannot be satisfactorily accounted for by climate models, nor yet definitively attributed either to unforced variability (such as the PDO) or forced climate change.

\section{Synthesis}

Recent analyses confirm the twentieth century sea level rise, with some studies showing a slightly smaller rate before 1990 and some a slightly larger value than reported in the AR5. There is now clearly more evidence of an acceleration in the rate of rise from the nineteenth to the twentieth century (as reported in the AR5); during the twentieth century, from the pre-1990 rate to the rate during the altimeter period, and with a positive (but not significant) rate in the altimeter record.

Ongoing ocean heat uptake and associated thermal expansion have continued and increased since 2000 (compared with previous decades), with a significant amount of heat being stored deeper in the water column and with the largest storage in the Southern Ocean. New estimates of global glacier mass loss indicate improved agreement between studies and thus smaller uncertainties over the twentieth century, but with little change in their average value. Two regional studies suggest glacier contributions to GMSL rise that are less than assessed by the AR5, but additional studies are required to assess the implications for the global estimates. The acceleration of mass loss from Greenland, primarily as a result of increased surface melting is continuing. Mass loss from the Antarctic ice sheet is 
Fig. 6 a CMIP5 model ensemble mean and $\mathbf{b}$ standard deviation of the forced patterns of ocean dynamic topography change $\left(\mathrm{m} /{ }^{\circ} \mathrm{C}\right)$ calculated using ocean volume mean temperature $\left({ }^{\circ} \mathrm{C}\right)$ as predictor for the historical + RCP4.5 simulations between 1993 and 2099. (From [144])
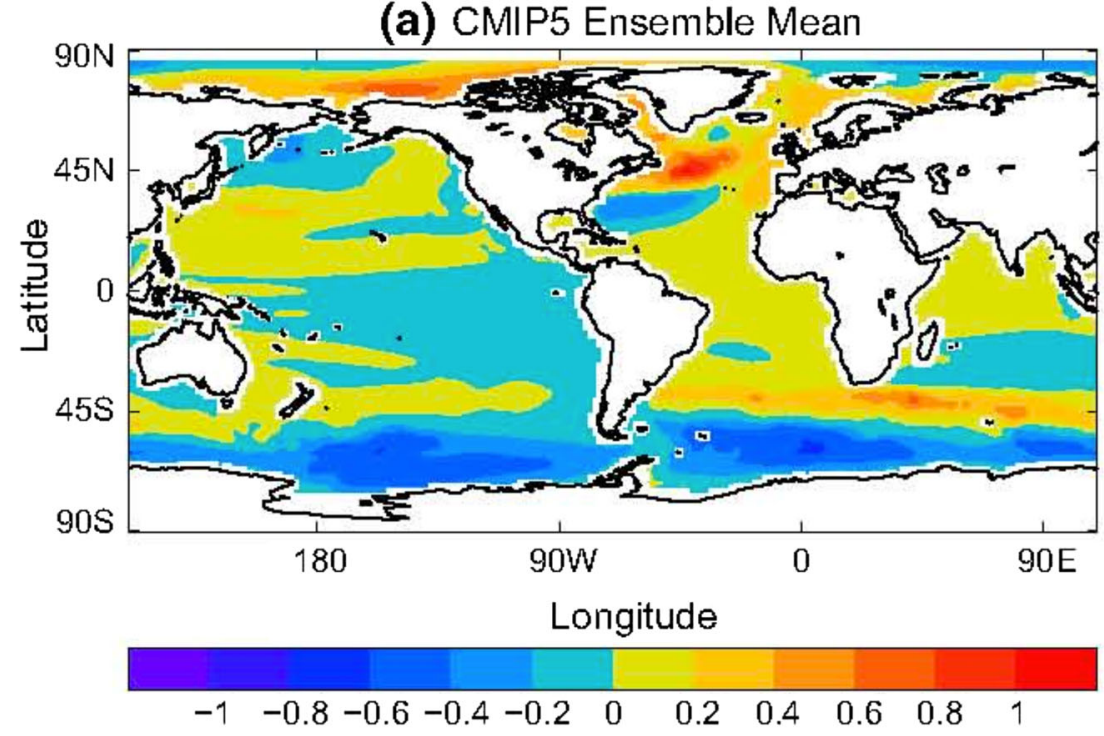

(b) CMIP5 Ensemble Std. Dev.

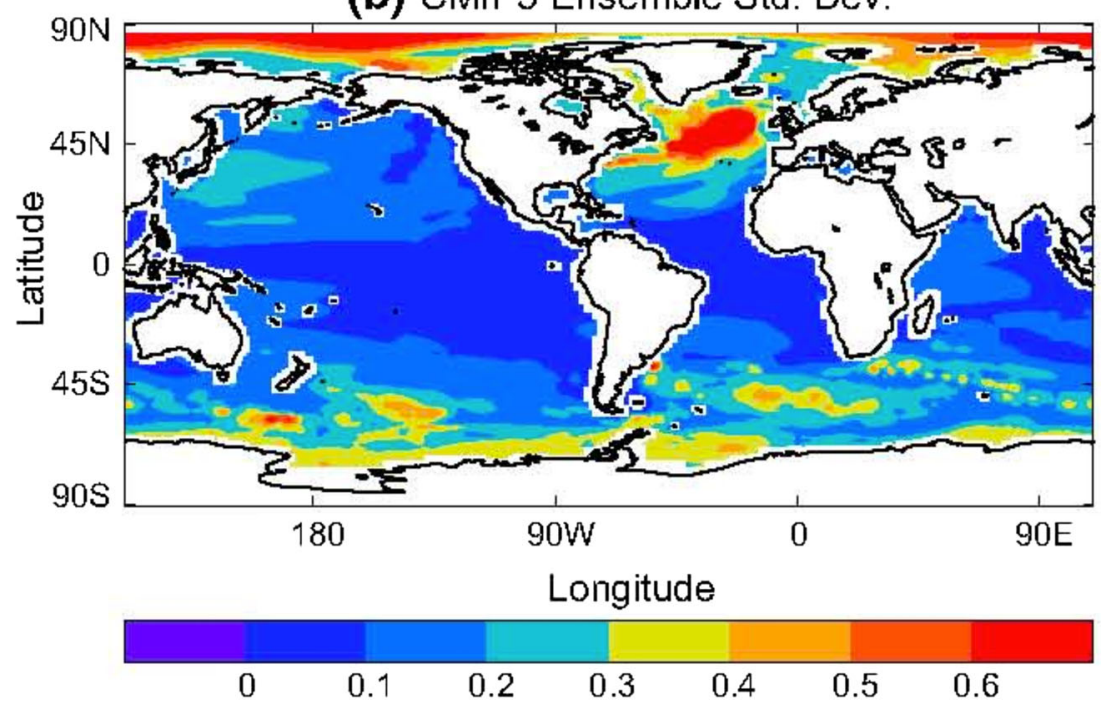

also accelerating, with most of that loss coming from discharge from the Amundsen Sea sector of the WAIS that is larger than the estimated increase in accumulation in East Antarctica. Observations and model simulations suggest that this acceleration may be associated with a marine ice sheet instability that may have been initiated in parts of the WAIS by an increased flux of CDW across the continental shelf. When the Antarctic and Greenland ice sheets are taken together, the estimated acceleration is larger than observed from the satellite altimeter sea level record, including at the upper end where their combined acceleration (range from 0.112 to $0.140 \mathrm{~mm} \mathrm{year}^{-2}$ ) exceeds that inferred from analysis of the satellite altimeter sea level record $\left(0.099 \mathrm{~mm} \mathrm{year}^{-2}\right)$ [38]. However, we note that the ice sheet estimates (2003-2013) are only for the latter half of the satellite altimeter period (1993 to mid-2014), during which time the sea level acceleration may be larger. Also, increased mass gain in land water storage and parts of East Antarctica, and decreased mass loss from glaciers in Alaska and some other regions such that the total acceleration in the ocean mass gain is consistent with the satellite altimeter record. There have not yet been any new comprehensive attempts to close the budget since 1900 or 1993, but it would appear that following the methodology of Gregory et al. [83], the sum of contributions can explain the observed rise.

The first formal detection studies for ocean thermal expansion and glacier mass loss, which were the two largest contributors to twentieth century GMSL rise, have confirmed the AR5 assessment of a significant anthropogenic contribution to sea level rise over the last 50 years.

Projections of mass loss from Greenland ice sheet discharge and SMB fall within the AR5 likely ranges, but differ 
from the AR5 in suggesting a greater contribution from SMB, a decreasing discharge as the ice sheet margin retreats from the coast, and with an insignificant contribution from enhanced basal lubrication. Post-AR5 studies of mass loss from the Greenland and Antarctic Ice Sheets by 2100, including a MISI contribution from parts of WAIS, suggest a contribution that falls largely within the likely range (i.e., two thirds probability) of the AR5.

Three post-AR5 studies of projections of twenty-first century GMSL derive a very likely range. However, these projections are based on expert elicitations and we have low confidence in deriving a very likely range in projections from such an approach.

Analyses of models indicate that the two commonly predicted features of future regional sea level change, namely the increasing tilt across the ACC and the dipole in the North Atlantic (both with enhanced sea level rise on their northern side), are related to regional changes in wind stress and surface heat flux. However, much remains to be understood about the geographical patterns and remote influences of surface flux changes, and their effects on ocean circulation and sea level. In particular, the east-west contrast in the Pacific of sea level trends observed since the early 1990s cannot be satisfactorily accounted for by climate models, nor yet definitely attributed either to unforced variability (such as the PDO) or forced climate change.

In view of the comparatively limited state of knowledge and understanding of rapid ice sheet dynamics, we continue to think that it is not yet possible to make reliable quantitative estimates of future GMSL rise outside the likely range. However, new ice sheet modeling results increase confidence in the AR5 likely range, indicating that there is a greater probability that sea level rise by 2100 will fall in that range with a corresponding decrease in the likelihood of an additional contribution of several tens of centimeters above the likely range.

Despite these uncertainties, it is clear that the sea level response to anthropogenic forcing will be detectable over most of the ocean by 2040 , confirming the importance of sea level change as a major issue that society will have to confront during the twenty-first century and beyond. The AR5 projections and the updates clearly indicate the rate of rise in 2100 is directly related to the future emissions and that avoiding a larger sea level rise will require significant and urgent mitigation of greenhouse gas emissions. As emphasized by Lowe and Gregory [167]: "It is vital to continue to monitor sea level and its components and to develop a capability to make reliable projections. [A]s we cannot provide certainties, we must become better at explaining the uncertainties to decision makers. These uncertainties imply a need to keep open a range of adaptation [and mitigation] options and to be able to change the approach as the predictions become more robust" (p. 43).
Acknowledgments PUC was supported by the US National Science Foundation Antarctic Glaciology Program (ANT-1043517) and the Marine Geology and Geophysics Program (OCE-1335197). JAC was supported by the Australian Government Department of the Environment, the Bureau of Meteorology and CSIRO through the Australian Climate Change Science Programme. We thank two reviewers for their helpful comments.

\section{Compliance with Ethical Standards}

Conflict of Interest On behalf of all authors, the corresponding author states that there is no conflict of interest.

Human and Animal Rights and Informed Consent This article does not contain any studies with human or animal subjects performed by any of the authors.

\section{References}

1. McGranahan G, Balk D, Anderson B. The rising tide: assessing the risks of climate change and human settlements in low elevation coastal zones. Environ Urban. 2007;19:17-37.

2. Lichter M, Vafeidis AT, Nicholls RJ, Kaiser G. Exploring datarelated uncertainties in analyses of land area and population in the 'low-elevation coastal zone' (LECZ). J Coast Res. 2011;27:75768.

3. Jongman B, Ward PJ, Aerts JCJH. Global exposure to river and coastal flooding: long term trends and changes. Glob Environ Chang Hum Pol Dimens. 2012;22:823-35.

4. Wong PP, Losada IJ, Gattuso J-P, Hinkel J, Khattabi A, McInnes $\mathrm{KL}$, et al. Coastal systems and low-lying areas. In: Field CB, Barros VR, Dokken DJ, Mach KJ, Mastrandrea MD, Bilir TE, Chatterjee M, Ebi KL, Estrada YO, Genova RC, Girma B, Kissel ES, Levy AN, MacCracken S, Mastrandrea PR, White LL, editors. Climate change 2014: impacts, adaptation, and vulnerability. Part A: Global and sectoral aspects. Contribution of Working Group II to the fifth assessment report of the intergovernmental panel on climate change. Cambridge: Cambridge University Press; 2014. p. 361-409.

5. Church JA, Clark PU, Cazenave A, Gregory JM, Jevrejeva S, Levermann A, et al. Sea level change. In: Stocker TF, Qin D, Plattner G-K, Tignor M, Allen SK, Boschung J, Nauels A, Xia Y, Bex V, Midgley PM, editors. Climate change 2013: the physical science basis. Contribution of Working Group I to the fifth assessment report of the intergovernmental panel on climate change. Cambridge: Cambridge University Press; 2013. p. 1137-216.

6. Collins M, Knutti R, Arblaster J, Dufresne J-L, Fichefet T, Friedlingstein $\mathrm{P}$, et al. Long-term climate change: projections, commitments and irreversibility. In: Stocker TF, Qin D, Plattner G-K, Tignor M, Allen SK, Boschung J, Nauels A, Xia Y, Bex V, Midgley PM, editors. Climate change 2013: the physical science basis. Contribution of Working Group I to the fifth assessment report of the intergovernmental panel on climate change. Cambridge: Cambrisge University Press; 2013. p. 1029-136.

7. Meehl GA, Stocker TF, Collins WD, Friedlingstein P, Gaye AT, Gregory JM, et al. Global climate projections. In: Solomon S, Qin D, Manning M, Chen Z, Marquis M, Averyt KB, Tignor M, Miller HL, editors. Climate change 2007: the physical science basis. Contribution of Working Group I to the fourth assessment report of the intergovernmental panel on climate change. Cambridge: Cambridge University Press; 2007. p. 748-845. 
8. Meinshausen M, Smith SJ, Calvin K, Daniel JS, Kainuma MLT, Lamarque JF, et al. The RCP greenhouse gas concentrations and their extensions from 1765 to 2300 . Clim Chang. 2011;109(1-2): 213-41.

9. Moss RH, Edmonds JA, Hibbard KA, Manning MR, Rose SK, van Vuuren DP, et al. The next generation of scenarios for climate change research and assessment. Nature. 2010;463(7282):74756.

10. Kerr RA. A stonger IPCC report. Science. 2013;342:43.

11. Rahmstorf S. Sea level in the 5th IPCC report. RealClimate.org; 2013.

12. Mooney C. The world's climate change watchdog may be underestimating global warming, Washington Post; 2014.

13. Church JA, Clark PU, Cazenave A, Gregory JM, Jevrejeva S, Levermann A, et al. Sea-level rise by 2100 . Science. 2013;342(6165):1445-5.

14. Rhein M, Rintoul SR, Aoki S, Campos E, Chambers D, Feely RA, et al. Observations: oceans. In: Stocker TF, Qin D, Plattner G-K, Tignor M, Allen SK, Boschung J, Nauels A, Xia Y, Bex V, Midgley PM, editors. Climate change 2013: the physical science basis. Contribution of Working Group I to the fifth assessment report of the intergovernmental panel on climate change. Cambridge: Cambridge University Press; 2013. p. 255-315.

15. Wenzel M, Schroter J. Global and regional sea level change during the 20th century. J Geophys Res-Oceans. 2014;119(11):7493508 .

16. Jevrejeva S, Moore JC, Grinsted A, Matthews AP, Spada G. Trends and acceleration in global and regional sea levels since 1807. Glob Planet Chang. 2014;113:11-22.

17. Hay CC, Morrow E, Kopp RE, Mitrovica JX. Probabilistic reanalysis of twentieth-century sea-level rise. Nature. 2015;517(7535): 481

18. Church JA, White NJ. Sea-level rise from the late 19th to the early 21st century. Surv Geophys. 2011;32:585-602.

19. Hamlington BD, Thompson PR. Considerations for estimating the 20th century trend in global mean sea level. Geophys Res Lett. 2015;42:4102-9.

20. Becker M, Karpytchev M, Lennartz-Sassinek S. Long-term sea level trends: natural or anthropogenic? Geophys Res Lett. 2014;41:5571-80.

21. Bos MS, Williams SDP, Araujo IB, Bastos L. The effect of temporal correlated noise on the sea level rate and acceleration uncertainty. Geophys J Int. 2014;196:1423-30.

22. Beenstock M, Felsenstein D, Frank E, Reingewertz Y. Tide gauge location and the measurement of global sea level rise. Environ Ecol Stat. 2015;22(1):179-206.

23. Dangendorf S, Marcos M, Muller A, Zorita E, Riva R, Berk K, Jensen J. Detecting anthropogenic footprints in sea level rise. Nat Commun. 2015. doi:10.1038/ncomms8849.

24. Visser H, Dangendorf S, Petersen AC. A review of trend models applied to sea level data with reference to the "acceleration-deceleration debate". J Geophys Res Oceans. 2015; 120.

25. Kenigson JS, Han W. Detecting and understanding the accelerated sea level rise along the east coast of the United States during recent decades. J Geophys Res Oceans. 2014;119(12):8749-66.

26. Piecuch CG, Ponte RM. Inverted barometer contributions to recent sea level changes along the northeast coast of North America. Geophys Res Lett. 2015;42(14):5918-25.

27. Haigh ID, Wahl T, Rohling EJ, Price RM, Pattiaratchi CB, Calafat FM, Dangendorf S. Timescales for detecting a significant acceleration in sea level rise. Nat Commun. 2014;5.

28. Douglas BC. Global sea-level acceleration. J Geophys Res Oceans. 1992;97:12699-706.

29. Cahill N, Kemp AC, Horton BP, Parnell AC. Modeling sea-level change using errors-in-variables integrated Gaussian processes. Ann Appl Stat. 2015;9(2):547-71.
30. Hogarth P. Preliminary analysis of acceleration of sea level rise through the twentieth century using extended tide gauge data sets (August 2014). J Geophys Res Oceans. 2014;119(11):7645-59.

31. Olivieri M, Spada G. Intermittent sea-level acceleration. Glob Planet Chang. 2013;109:64-72.

32. Spada G, Olivieri M, Galassi G. A heuristic evaluation of longterm global sea level acceleration. Geophys Res Lett. 2015;42: 4166-72.

33. Jorda G. Detection time for global and regional sea level trends and accelerations. J Geophys Res Oceans. 2014;119(10):7164-74.

34. Cazenave A, Dieng HB, Meyssignac B, von Schuckmann K, Decharme B, Berthier E. The rate of sea-level rise. Nat Clim Chang. 2014;4(5):358-61.

35. Fasullo JT, Boening C, Landerer FW, Nerem RS. Australia's unique influence on global sea level in 2010-2011. Geophys Res Lett. 2013;40(16):4368-73.

36. Yi S, Sun W, Heki K, Qian A. An increase in the rate of global mean sea level rise since 2010. Geophys Res Lett. 2015;42:39984006.

37. Ablain M, Cazenave A, Larnicol G, Balmaseda M, Cipollini P, Faugere Y, et al. Improved sea level record over the satellite altimetry era $(1993-2010)$ from the climate change initiative project. Ocean Sci. 2015;11(1):67-82.

38. Watson CS, White NJ, Church JA, King MA, Burgette RJ, Legresy B. Unabated global mean sea-level rise over the satellite altimeter era. Nat Clim Chang. 2015.

39. Wu X, Heflin MB. A global assessment of accelerations in surface mass transport. Geophys Res Lett. 2015;42:6716-23.

40. Lyman JM, Good SA, Gouretski VV, Ishii M, Johnson GC, Palmer MD, et al. Robust warming of the global upper ocean. Nature. 2010;465(7296):334-7.

41. Church JA, White NJ, Konikow LF, Domingues CM, Cogley JG, Rignot E, Gregory JM, van den Broeke MR, Monaghan AJ, Velicogna I. Revisiting the earth's sea-level and energy budgets from 1961 to 2008. Geophys Res Lett. 2011b; 38.

42. Church JA, White NJ, Konikow LF, Domingues CM, Cogley JG, Rignot E, et al. Revisiting the earth's sea-level and energy budgets from 1961 to 2008 (vol 38, L18601, 2011). Geophys Res Lett. 2013;40(15):4066-6.

43. Abraham JP, Baringer M, Bindoff NL, Boyer T, Cheng LJ, Church JA, et al. A review of global ocean temperature observations: implications for ocean heat content estimates and climate change. Rev Geophys. 2013;51(3):450-83.

44. Cheng L, Zhu J. Influences of the choice of climatology on ocean heat content estimation. J Atmos Ocean Technol. 2014;32(2):38894.

45. Cheng L, Zhu J. Uncertainties of the ocean heat content estimation induced by insufficient vertical resolution of historical ocean subsurface observations. J Atmos Ocean Technol. 2014;31(6):138396.

46. Chang Y-S, Vecchi GA, Rosati A, Zhang S, Yang X. Comparison of global objective analyzed T-S fields of the upper ocean for 2008-2011. J Mar Syst. 2014;137:13-20.

47. Balmaseda MA, Trenberth KE, Källén E. Distinctive climate signals in reanalysis of global ocean heat content. Geophys Res Lett. 2013;40(9):1754-9.

48. Chen X, Tung K-K. Varying planetary heat sink led to globalwarming slowdown and acceleration. Science. 2014;345(6199): 897-903.

49. Domingues CM, Church JA, White NJ, Gleckler PJ, Wijffels SE, Barker PM, et al. Improved estimates of upper-ocean warming and multi-decadal sea-level rise. Nature. 2008;453(7198):1090.

50. Nieves V, Willis JK, Patzert WC. Recent hiatus caused by decadal shift in Indo-Pacific heating. Science. 2015;349(6247):532-5. 
51. Palmer MD, McNeall DJ. Internal variability of earth's energy budget simulated by CMIP5 climate models. Environ Res Lett. 2014;9(3):034016.

52. Allan RP, Liu C, Loeb NG, Palmer MD, Roberts M, Smith D, et al. Changes in global net radiative imbalance 1985-2012. Geophys Res Lett. 2014;41(15):5588-97.

53. Loeb NG, Lyman JM, Johnson GC, Allan RP, Doelling DR, Wong $\mathrm{T}$, et al. Observed changes in top-of-the-atmosphere radiation and upper-ocean heating consistent within uncertainty. Nat Geosci. 2012;5(2):110-3.

54. Smith DM, Allan RP, Coward AC, Eade R, Hyder P, Liu C, Loeb NG, Palmer MD, Roberts CD, Scaife AA. Earth's energy imbalance since 1960 in observations and CMIP5 models. Geophys Res Lett. 2015;42(4): 2014GL062669.

55. Wunsch C, Heimbach P. Bidecadal thermal changes in the abyssal ocean. J Phys Oceanogr. 2014;44(8):2013-30.

56. Purkey SG, Johnson GC. Warming of global abyssal and deep southern ocean waters between the 1990s and 2000s: contributions to global heat and sea level rise budgets. J Clim. 2010;23(23):6336-51.

57. Leuliette E. The balancing of the sea-level budget. Curr Clim Chang Rep. 2015;1:1-7.

58. von Schuckmann K, Sallée JB, Chambers D, Le Traon PY, Cabanes C, Gaillard F, et al. Consistency of the current global ocean observing systems from an Argo perspective. Ocean Sci. 2014;10(3):547-57.

59. Dieng H, Palanisamy H, Cazenave A, Meyssignac B, von Schuckmann K. The sea level budget since 2003: inference on the deep ocean heat content. Surv Geophys. 2015;36(2):209-29.

60. Llovel W, Willis JK, Landerer FW, Fukumori I. Deep-ocean contribution to sea level and energy budget not detectable over the past decade. Nat Clim Chang. 2014;4:1031-5.

61. Durack PJ, Gleckler PJ, Landerer FW, Taylor KE. Quantifying underestimates of long-term upper-ocean warming. Nat Clim Chang. 2014;4(11):999-1005.

62. Levitus S, Antonov JI, Boyer TP, Baranova OK, Garcia HE, Locarnini RA, et al. World ocean heat content and thermosteric sea level change (0-2000 m), 1955-2010. Geophys Res Lett. 2012;39(10), L10603.

63. Roemmich D, Church J, Gilson J, Monselesan D, Sutton P, Wijffels S. Unabated planetary warming and its ocean structure since 2006. Nat Clim Chang. 2015;5(3):240-5.

64. Purkey SG, Johnson GC, Chambers DP. Relative contributions of ocean mass and deep steric changes to sea level rise between 1993 and 2013. J Geophys Res-Earth Surf. 2014;119(11):7509-22.

65. Marzeion B, Leclercq PW, Cogley JG, Jarosch AH. Brief communication: global glacier mass loss reconstructions during the 20th century are consistent. Cryosphere Discuss. 2015;9:3807-20.

66. Vaughan DG, Comiso JC, Allison I, Carrasco J, Kaser G, Kwok R, et al. Observations: cryosphere. In: Stocker TF, Qin D, Plattner GK, Tignor M, Allen SK, Boschung J, Nauels A, Xia Y, Bex V, Midgley PM, editors. Climate change 2013: the physical science basis. Contribution of Working Group I to the fifth assessment report of the intergovernmental panel on climate change. Cambridge: Cambridge University Press; 2013. p. 317-82.

67. Csatho BM, Schenk AF, van der Veen CJ, Babonis G, Duncan K, Rezvanbehbahani $\mathrm{S}$, et al. Laser altimetry reveals complex pattern of Greenland ice sheet dynamics. Proc Natl Acad Sci U S A. 2014;111(52):18478-83.

68. Velicogna I, Sutterley TC, van den Broeke MR. Regional acceleration in ice mass loss from Greenland and Antarctica using GRACE time-variable gravity data. Geophys Res Lett. 2014;41: 8130-7.

69. Enderlin EM, Howat IM, Jeong S, Noh MJ, van Angelen JH, van den Broeke MR. An improved mass budget for the Greenland ice sheet. Geophys Res Lett. 2014;41(3):866-72.
70. Wouters B, Bamber JL, van den Broeke MR, Lenaerts JTM, Sasgen I. Limits in detecting acceleration of ice sheet mass loss due to climate variability. Nat Geosci. 2013;6(8):613-6.

71. Helm V, Humbert A, Miller H. Elevation and elevation change of Greenland and Antarctica derived from CryoSat-2. Cryosphere. 2014;8(4):1539-59.

72. Khan SA, Kjaer KH, Bevis M, Bamber JL, Wahr J, Kjeldsen KK, et al. Sustained mass loss of the northeast Greenland ice sheet triggered by regional warming. Nat Clim Chang. 2014;4(4):2929.

73. van Angelen JH, van den Broeke MR, Wouters B, Lenaerts JTM. Contemporary (1960-2012) evolution of the climate and surface mass balance of the Greenland ice sheet. Surv Geophys. 2014;35(5):1155-74.

74. Lenaerts JTM, van Meijgaard E, van den Broeke MR, Ligtenberg SRM, Horwath M, Isaksson E. Recent snowfall anomalies in Dronning Maud Land, East Antarctica, in a historical and future climate perspective. Geophys Res Lett. 2013;40(11):2684-8.

75. Harig C, Simons FJ. Accelerated West Antarctic ice mass loss continues to outpace East Antarctic gains. Earth Planet Sci Lett. 2015;415:134-41.

76. McMillan M, Shepherd A, Sundal A, Briggs K, Muir A, Ridout A, et al. Increased ice losses from Antarctica detected by CryoSat-2. Geophys Res Lett. 2014;41(11):3899-905.

77. Sutterley TC, Velicogna I, Rignot E, Mouginot J, Flament T, van den Broeke MR, et al. Mass loss of the Amundsen Sea Embayment of West Antarctica from four independent techniques. Geophys Res Lett. 2014;41(23):8421-8.

78. Rignot E, Mouginot J, Morlighem M, Seroussi H, Scheuchl B. Widespread, rapid grounding line retreat of Pine Island, Thwaites, Smith, and Kohler glaciers, West Antarctica, from 1992 to 2011. Geophys Res Lett. 2014;41(10):3502-9.

79. Favier L, Durand G, Cornford SL, Gudmundsson GH, Gagliardini $\mathrm{O}$, Gillet-Chaulet F, et al. Retreat of Pine Island Glacier controlled by marine ice-sheet instability. Nat Clim Chang. 2014;4(2):11721.

80. Joughin I, Smith BE, Medley B. Marine ice sheet collapse potentially under way for the Thwaites Glacier Basin, West Antarctica. Science. 2014;344(6185):735-8.

81. Schmidtko S, Heywood KJ, Thompson AF, Aoki S. Multidecadal warming of Antarctic waters. Science. 2014;346(6214):1227-31.

82. Paolo FS, Fricker HA, Padman L. Volume loss from Antarctic ice shelves is accelerating. Science. 2015;348(6232):327-31.

83. Gregory JM, White NJ, Church JA, Bierkens MFP, Box JE, van den Broeke MR, et al. Twentieth-century global-mean sea level rise: is the whole greater than the sum of the parts? J Clim. 2013;26:4476-99.

84. Bindoff NL, Stott PA, AchutaRao KM, Allen MR, Gillett N, Gutzler D, et al. Detection and attribution of climate change: from global to regional. In: Stocker TF, Qin D, Plattner G-K, Tignor M, Allen SK, Boschung J, Nauels A, Xia Y, Bex V, Midgley PM, editors. Climate change 2013: the physical science basis. Contribution of Working Group I to the fifth assessment report of the intergovernmental panel on climate change. Cambridge: Cambridge University Press; 2013. p. 867-952.

85. Marcos M, Amores A. Quantifying anthropogenic and natural contributions to thermosteric sea level rise. Geophys Res Lett. 2014;41(7):2502-7.

86. Slangen ABA, Church JA, Zhang XB, Monselesan D. Detection and attribution of global mean thermosteric sea level change. Geophys Res Lett. 2014;41(16):5951-9.

87. Marzeion B, Cogley JG, Richter K, Parkes D. Attribution of global glacier mass loss to anthropogenic and natural causes. Science. 2014;345(6199):919-21.

88. Church JA, Clark PU, Cazenave A, Gregory JM, Jevrejeva S, Levermann A, et al. Sea level change supplementary material. 
In: Stocker TF, Qin D, Plattner G-K, Tignor M, Allen SK, Boschung J, Nauels A, Xia Y, Bex V, Midgley PM, editors. Climate change 2013: the physical science basis. Contribution of Working Group I to the fifth assessment report of the intergovernmental panel on climate change. Cambridge: Cambridge University Press; 2013. p. 13SM-1-8.

89. Clarke GKC, Jarosch AH, Anslow FS, Radic V, Menounos B. Projected deglaciation of western Canada in the twenty-first century. Nat Geosci. 2015;8(5):372-7.

90. Marzeion B, Jarosch AH, Hofer M. Past and future sea-level change from the surface mass balance of glaciers. Cryosphere. 2012;6(6):1295-322.

91. Marzeion B, Jarosch AH, Gregory JM. Feedbacks and mechanisms affecting the global sensitivity of glaciers to climate change. Cryosphere. 2014;8(1):59-71.

92. Lang C, Fettweis X, Erpicum M. Future climate and surface mass balance of Svalbard glaciers in an RCP8.5 climate scenario: a study with the regional climate model MAR forced by MIROC5. Cryosphere. 2015;9(3):945-56.

93. Radic V, Bliss A, Beedlow AC, Hock R, Miles E, Cogley JG. Regional and global projections of twenty-first century glacier mass changes in response to climate scenarios from global climate models. Clim Dyn. 2014;42:37-58.

94. Fettweis X, Franco B, Tedesco M, van Angelen JH, Lenaerts JTM, van den Broeke MR, et al. Estimating Greenland ice sheet surface mass balance contribution to future sea level rise using the regional atmospheric model MAR. Cryosphere. 2013;7:469-89.

95. Nick FM, Vieli A, Andersen ML, Joughin I, Payne A, Edwards TL, et al. Future sea-level rise from Greenland's main outlet glaciers in a warming climate. Nature. 2013;497(7448):235-8.

96. Joughin I, Das SB, King MA, Smith BE, Howat IM, Moon T. Seasonal speedup along the western flank of the Greenland ice sheet. Science. 2008;320(5877):781-3.

97. Zwally HJ, Abdalati W, Herring T, Larson K, Saba J, Steffen K. Surface melt-induced acceleration of Greenland ice-sheet flow. Science. 2002;297:218-22.

98. Leeson AA, Shepherd A, Briggs K, Howat I, Fettweis X, Morlighem M, et al. Supraglacial lakes on the Greenland ice sheet advance inland under warming climate. Nat Clim Chang. 2015;5(1):51-5.

99. Sole A, Nienow P, Bartholomew I, Mair D, Cowton T, Tedstone $A$, et al. Winter motion mediates dynamic response of the Greenland ice sheet to warmer summers. Geophys Res Lett. 2013;40:3940-4.

100. Sundal AV, Shepherd A, Nienow P, Hanna E, Palmer S, Huybrechts P. Melt-induced speed-up of Greenland ice sheet offset by efficient subglacial drainage. Nature. 2011;469:521-4.

101. Mayaud JR, Banwell AF, Arnold NS, Willis IC. Modeling the response of subglacial drainage at Paakitsoq, west Greenland, to 21 st century climate change. J Geophys Res-Earth Surf. 2014;119(12):2619-34.

102. Shannon SR, Payne AJ, Bartholomew ID, van den Broeke MR, Edwards TL, Fettweis X, et al. Enhanced basal lubrication and the contribution of the Greenland ice sheet to future sea-level rise. Proc Natl Acad Sci U S A. 2013;110(35):14156-61.

103. Edwards TL, Fettweis X, Gagliardini O, Gillet-Chaulet F, Goelzer $\mathrm{H}$, Gregory JM, et al. Effect of uncertainty in surface mass balanceelevation feedback on projections of the future sea level contribution of the Greenland ice sheet. Cryosphere. 2014;8(1):195-208.

104. Fürst JJ, Goelzer H, Huybrechts P. Ice-dynamic projections of the Greenland ice sheet in response to atmospheric and oceanic warming. Cryosphere. 2015;9:1039-62.

105. Rignot E, Jacobs S, Mouginot J, Scheuchl B. Ice-shelf melting around Antarctica. Science. 2013;341(6143):266-70.

106. Seroussi H, Morlighem M, Rignot E, Mouginot J, Larour E, Schodlok M, et al. Sensitivity of the dynamics of Pine Island
Glacier, West Antarctica, to climate forcing for the next 50 years. Cryosphere. 2014;8(5):1699-710.

107. Gong Y, Cornford SL, Payne AJ. Modelling the response of the Lambert Glacier-Amery ice shelf system, East Antarctica, to uncertain climate forcing over the 21 st and 22 nd centuries. Cryosphere. 2014;8(3):1057-68.

108. Sun S, Cornford SL, Liu Y, Moore JC. Dynamic response of Antarctic ice shelves to bedrock uncertainty. Cryosphere. 2014;8(4):1561-76.

109. Cornford SL, Martin DF, Payne AJ, Ng EG, Le Brocq AM, Gladstone RM, et al. Century-scale simulations of the response of the West Antarctic ice sheet to a warming climate. Cryosphere Discuss. 2015;9(2):1887-942.

110. Levermann A, Winkelmann R, Nowicki S, Fastook JL, Frieler K, Greve R, et al. Projecting Antarctic ice discharge using response functions from SeaRISE ice-sheet models. Earth Syst Dyn. 2014;5(2):271-93

111. Hellmer HH, Kauker F, Timmermann R, Determann J, Rae J. Twenty-first-century warming of a large Antarctic ice-shelf cavity by a redirected coastal current. Nature. 2012;485:225-8.

112. Wright AP, Le Brocq AM, Cornford SL, Bingham RG, Corr HFJ, Ferraccioli F, et al. Sensitivity of the Weddell sea sector ice streams to sub-shelf melting and surface accumulation. Cryosphere. 2014;8(6):2119-34.

113. Pollard D, DeConto RM, Alley RB. Potential Antarctic ice sheet retreat driven by hydrofracturing and ice cliff failure. Earth Planet Sci Lett. 2015;412:112-21.

114. Kuipers Munneke P, Ligtenberg SRM, van den Broeke MR, Vaughan DG. Firn air depletion as a precursor of Antarctic iceshelf collapse. J Glaciol. 2014;60(220):205-14.

115. MacAyeal DR, Scambos TA, Hulbe CL, Fahnestock MA. Catastrophic ice-shelf break-up by an ice-shelf-fragment-capsize mechanism. J Glaciol. 2003;49:22-36.

116. Nowicki S, Bindschadler RA, Abe-Ouchi A, Aschwanden A, Bueler E, Choi H, et al. Insights into spatial sensitivities of ice mass response to environmental change from the SeaRISE ice sheet modeling project I: Antarctica. J Geophys Res-Earth Surf. 2013;118:1002-24.

117. Orlic M, Pasaric Z. Some pitfalls of the semiempirical method used to project sea level. J Clim. 2015;28(9):3779-85.

118. Horton B, Rahmstorf S, Engelhart SE, Kemp AC. Expert assessment of sea-level rise by AD 2100 and AD 2300. Quat Sci Rev. 2014;84:1-6.

119. Gregory JM, Church JA, Clark PU, Payne AJ, Merrifield MA, Nerem RS, et al. Comment on "Expert assessment of sea-level rise by AD 2100 and AD 2300", by Horton et al. (2014). Quat Sci Rev. 2014;97:193-4.

120. Kopp RE, Horton RM, Little CM, Mitrovica JX, Oppenheimer M, Rasmussen DJ, et al. Probabilistic 21st and 22nd century sea-level projections at a global network of tide-gauge sites. Earth's Futur. 2014;2:383-406

121. Jevrejeva S, Grinsted A, Moore JC. Upper limit for sea level projections by 2100. Environ Res Lett. 2014a; 9(10).

122. Bamber JL, Aspinall WP. An expert judgement assessment of future sea level rise from the ice sheets. Nat Clim Chang. 2013;3:424-7.

123. Pfeffer WT, Harper JT, O'Neel S. Kinematic constraints on glacier contributions to 21 st-century sea-level rise. Science. 2008;321: 1340-3.

124. Kopp RE, Hay CC, Little CM, Mitrovica JX. Geographic variability of sea-level change. Current Climate Change Reports; 2015.

125. Katsman CA, Sterl A, Beersma JJ, van den Brink HW, Church JA, Hazeleger W, et al. Exploring high-end scenarios for local sea level rise to develop flood protection strategies for a low-lying delta - the Netherlands as an example. Clim Chang. 2011;109: 617-45. 
126. Slangen ABA, Katsman CA, van de Wal RSW, Vermeersen LLA, Riva REM. Towards regional projections of twenty-first century sea-level change based on IPCC SRES scenarios. Clim Dyn. 2012;38:1191-209.

127. Church JA, Gregory JM, White NJ, Platten SM, Mitrovica JX. Understanding and projecting sea level change. Oceanography. 2011;24(2):130-43.

128. Carson M, Kohl A, Stammer D, Slangen A, Katsman CCA, van de Wal RSW, Church J, White N. Coastal sea level changes, observed and projected during the 20th and 21 st century. Climate Dynamics; 2015b.

129. CSIRO, A.B.o.M.a. Climate variability, extremes and change in the western tropical Pacific: new science and updated country reports, Pacific-Australia climate change science and adaptation planning program technical report. Melbourne: Australian Bureau of Meteorology and Commonwealth Scientific and Industrial Research Organisation; 2014.

130. Han G, Ma Z, Bao H, Slangen A. Regional differences of relative sea level changes in the Northwest Atlantic: historical trends and future projections. J Geophys Res Oceans. 2014;119(1):156-64.

131. Hunter JR, Church JA, White NJ, Zhang X. Towards a global regionally varying allowance for sea-level rise. Ocean Eng. 2013;71:17-27.

132. Little CM, Horton RM, Kopp RE, Oppenheimer M, Yip S. Uncertainty in twenty-first-century CMIP5 sea level projections. J Clim. 2015;28(2):838-52.

133. McInnes KL, Church JA, Monselesan D, Hunter JR, O'Grady JG, Haigh ID, Zhang X. Sea-level rise projections for Australia: information for impact and adaptation planning. Aust Meteorol Oceanogr J. 2015.

134. Simpson MR, Breili K, Kierulf H. Estimates of twenty-first century sea-level changes for Norway. Clim Dyn. 2014;42(5-6): 1405-24.

135. Slangen ABA, Carson M, Katsman CA, van de Wal RSW, Kohl A, Vermeersen LLA, et al. Projecting twenty-first century regional sea-level changes. Clim Chang. 2014;124(1-2):317-32.

136. Pardaens AK, Gregory JM, Lowe JA. A model study of factors influencing projected changes in regional sea level over the twenty-first century. Clim Dyn. 2011;36(9-10):2015-33.

137. Bouttes N, Gregory JM, Kuhlbrodt T, Suzuki T. The effect of windstress change on future sea level change in the Southern Ocean. Geophys Res Lett. 2012;39.

138. Yin JJ. Century to multi-century sea level rise projections from CMIP5 models. Geophys Res Lett. 2012; 39.

139. Bouttes N, Gregory JM. Attribution of the spatial pattern of CO2forced sea level change to ocean surface flux changes. Environ Res Lett. 2014; 9(3).

140. Frankcombe LM, Spence P, Hogg AM, England MH, Griffies SM. Sea level changes forced by Southern Ocean winds. Geophys Res Lett. 2013;40(21):5710-5.

141. Cai WJ, Cowan T. Trends in Southern Hemisphere circulation in IPCC AR4 models over 1950-99: ozone depletion versus greenhouse forcing. J Clim. 2007;20(4):681-93.

142. Thompson DWJ, Solomon S, Kushner PJ, England MH, Grise KM, Karoly DJ. Signatures of the Antarctic ozone hole in Southern Hemisphere surface climate change. Nat Geosci. 2011;4(11):741-9.

143. Suzuki T, Ishii M. Regional distribution of sea level changes resulting from enhanced greenhouse warming in the model for interdisciplinary research on climate version 3.2. Geophys Res Lett. 2011;38:L02601.

144. Bilbao RAF, Gregory JM, Bouttes N. Analysis of the regional pattern of sea level change due to ocean dynamics and density change for 1993-2099 in observations and CMIP5 AOGCMs. Climate Dynamics; 2015.
145. Bouttes N, Gregory JM, Kuhlbrodt T, Smith RS. The drivers of projected North Atlantic sea level change. Clim Dyn. 2014;43(56): $1531-44$.

146. Swingedouw D, Rodehacke CB, Behrens E, Menary M, Olsen $\mathrm{SM}, \mathrm{Gao} \mathrm{YQ}$, et al. Decadal fingerprints of freshwater discharge around Greenland in a multi-model ensemble. Clim Dyn. 2013;41(3-4):695-720.

147. Yin JJ, Schlesinger ME, Stouffer RJ. Model projections of rapid sea-level rise on the northeast coast of the United States. Nat Geosci. 2009;2(4):262-6.

148. Howard T, Ridley J, Pardaens AK, Hurkmans RTWL, Payne AJ, Giesen RH, et al. The land-ice contribution to 21st-century dynamic sea level rise. Ocean Sci. 2014;10(3):485-500.

149. England MH, McGregor S, Spence P, Meehl GA, Timmermann A, Cai WJ, et al. Recent intensification of wind-driven circulation in the Pacific and the ongoing warming hiatus. Nat Clim Chang. 2014;4(3):222-7.

150. Griffies SM, Yin JJ, Durack PJ, Goddard P, Bates SC, Behrens E, et al. An assessment of global and regional sea level for years 1993-2007 in a suite of interannual CORE-II simulations. Ocean Model. 2014;78:35-89.

151. Hamlington BD, Leben RR, Strassburg MW, Nerem RS, Kim KY. Contribution of the Pacific decadal oscillation to global mean sea level trends. Geophys Res Lett. 2013;40:5171-5.

152. Hamlington BD, Strassburg MW, Leben RR, Han W, Nerem RS, Kim KY. Uncovering an anthropogenic sea-level rise signal in the Pacific Ocean. Nat Clim Chang. 2014;4(9):782-5.

153. Merrifield MA, Thompson PR, Lander M. Multidecadal sea level anomalies and trends in the western tropical Pacific. Geophys Res Lett. 2012;39, L13602.

154. Zhang XB, Church JA. Sea level trends, interannual and decadal variability in the Pacific Ocean. Geophys Res Lett. 2012; 39.

155. Frankcombe LM, McGregor S, England MH. Robustness of the modes of Indo-Pacific sea level variability. Clim Dyn. 2015;45(56):1281-98.

156. Palanisamy H, Meyssignac B, Cazenave A, Delcroix T. Is anthropogenic sea level fingerprint already detectable in the Pacific Ocean? Environ Res Lett. 2015;10:084024.

157. Carson M, Kohl A, Stammer D. The impact of regional multidecadal and century-scale internal climate variability on sea level trends in CMIP5 models. J Clim. 2015;28(2):853-61.

158. England MH, Kajtar JB, Maher N. Robust warming projections despite the recent hiatus. Nat Clim Chang. 2015;5:394-6.

159. Kosaka Y, Xie S-P. Recent global-warming hiatus tied to equatorial Pacific surface cooling. Nature. 2013;501:403-7.

160. Meehl GA, Arblaster JM, Fasullo JY, Hu A, Trenberth KE. Modelbased evidence of deep-ocean heat uptake during surfacetemperature hiatus periods. Nat Clim Chang. 2011;1:360-4.

161. Hu AX, Deser C. Uncertainty in future regional sea level rise due to internal climate variability. Geophys Res Lett. 2013;40(11): 2768-72.

162. Bordbar MH, Martin T, Latif M, Park W. Effects of long-term variability on projections of twenty-first-century dynamic sea level. Nat Clim Chang. 2015;5(4):343-7.

163. Hawkins E, Sutton R. Time of emergence of climate signals. Geophys Res Lett. 2012; 39.

164. Lyu KW, Zhang XB, Church JA, Slangen ABA, Hu JY. Time of emergence for regional sea-level change. Nat Clim Chang. 2014;4(11):1006-10.

165. Richter K, Marzeion B. Earliest local emergence of forced dynamic and steric sea-level trends in climate models. Environ Res Lett. $2014 ; 9(11)$

166. Slangen A, Church JA, Zhang X, Monselesan D. The sea-level response to external forcings in CMIP5 climate models. J Clim. 2015.

167. Lowe J, Gregory JM. A sea of uncertainty. Nat Rep Clim Chang. 2010;4:42-3. 